\title{
Natural compositional variation of the river Meuse (Maas) suspended load: a 13 ka bulk geochemical record from the upper Kreftenheye and Betuwe Formations in northern Limburg
}

\author{
L.A. Tebbens ${ }^{1,2}$, A. Veldkamp ${ }^{1,3}$ \& S.B. Kroonenberg ${ }^{4}$
}

1 Laboratory of Soil Science and Geology, Wageningen Agricultural University, P.O. Box 37, 6700 AA WAGENINGEN, the Netherlands

2 corresponding author; e-mail: Leo.Tebbens@geog.uu.nl

3 e-mail:Tom.Veldkamp@geomin.beng.wau.nl

${ }^{4}$ Department of Applied Earth Sciences, Delft Technical University, Mijnbouwstraat 120, 2628 RX, DELFT, the Netherlands; e-mail: S.B.Kroonenberg@mp.tudelft.nl

Manuscript received: 15 September 1998; accepted in revised form: 14 June 2000

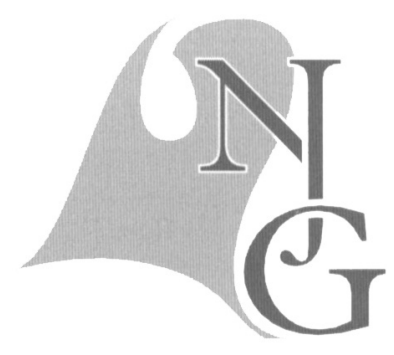

\begin{abstract}
Unambiguously pristine and largely unpolluted sediments from the Late Weichselian and Holocene infillings of the Meuse residual channels in northern Limburg (the Netherlands) have been sampled to determine the natural compositional variation of the river's suspended load.

Bulk geochemical and granulometric analyses demonstrate that about $70 \%$ of the variation can be ascribed to hydrodynamic mineral sorting. Clay- and fine silt-sized phyllosilicates are the most important deterministic features, hosting the bulk of $\mathrm{Al}_{2} \mathrm{O}_{3}, \mathrm{TiO}_{2}, \mathrm{~K}_{2} \mathrm{O}, \mathrm{MgO}$ and trace element variability (notably $\mathrm{Ba}, \mathrm{Cr}, \mathrm{Ga}, \mathrm{Rb}$ and $\mathrm{V}$ ). Quartz is abundant in the fine and coarse sand fractions. $\mathrm{Na}_{2} \mathrm{O}$ and the $\mathrm{Zr}-\mathrm{Nb}-\mathrm{Nd}-\mathrm{Y}$ quartet relate to albitic feldspars and heavy minerals, respectively, in the coarse silt fraction. The granulometry should therefore be quantified if geochemical baseline data for a particular geological unit or region are drawn up and for the evaluation of potentially polluted sediments.

Although provenance has not changed, the composition of Meuse sediments cannot be considered constant over a time frame of 1000-10,000 years, due to climatic change. Weathering of phyllosilicates in both interstadial and interglacial soil environments and changing relative source-area contributions alter the detrital clay-mineral supply to raise the $\mathrm{Al}_{2} \mathrm{O}_{3}$ and lower the $\mathrm{K}_{2} \mathrm{O}$ and $\mathrm{MgO}$ contents in Holocene Meuse sediments. Early diagenetic siderite and vivianite formation in gyttjas causes relative accumulations of $\mathrm{Fe}_{2} \mathrm{O}_{3}, \mathrm{MnO}, \mathrm{P}_{2} \mathrm{O}_{5}, \mathrm{Co}, \mathrm{Ni}$ and notably $\mathrm{Zn}$ above the phyllosilicate background values. These accumulations are natural and show that sediments with elevated trace metal contents are not necessarily polluted. Very early atmospheric pollution in relation to ore mining and smelting activities in the Roman era, however, probably caused elevated $\mathrm{Pb}$ contents in Subatlantic humic clays and peat samples, long before the historic pollution of the Industrial Revolution started.

The $\mathrm{Al}_{2} \mathrm{O}_{3}, \mathrm{Fe}_{2} \mathrm{O}_{3}$ and $\mathrm{CaO}$ contents are used to predict the trace-element values as a function of sample granulometry, siderite/vivianite and lime content, respectively. As such, they can provide a sound basis for environmental researchers to determine baseline values of heavy metals in bulk samples of fine-grained fluvial sediments.
\end{abstract}

Keywords: bulk geochemistry, natural background, overbank sediments, residual channel fillings

\section{Introduction}

Geochemical appraisal of soils and sediments has become increasingly important during the last decade. In both the Netherlands and other densely populated areas, there is a growing need for geochemical baseline data to define the natural compositional variation of the grounds we live on (Darnley et al., 1995; Darn- ley, 1997). Geochemical baseline data account for regional and local geological variation and constitute the natural background values to which presumed polluted samples can be compared. As such, they are indispensable because they provide a sound and realistic basis for environmental legislation and policy making (Salminen \& Tarvainen, 1997; Plant et al., 1997). The pollution of overbank and floodplain sedi- 
ments of the Meuse (in Dutch: Maas) and its tributary, Geul, with $\mathrm{Pb}, \mathrm{Zn}, \mathrm{Cu}$ and $\mathrm{Cd}$ due to ore mining in Belgium certainly began more than 350 years ago (Leenaers, 1989; Rang \& Schouten, 1989). During two major flooding events in the Netherlands in 1993 and 1995, public concern arose with respect to the degree of pollution of the present suspended load of the Rhine and Meuse rivers (Bleichrodt \& Ensinck, 1994; Goudriaan, 1995; Asselman \& Middelkoop, 1996; Wolterbeek et al., 1996). Surprisingly little is known, however, about the natural background values of major and trace elements of fine-grained sediments within the floodplains of these rivers.

Moura \& Kroonenberg (1990) and Hakstege et al. (1993) were the first to describe the bulk geochemistry of Quaternary Rhine and Meuse sediments by sampling deposits of diverse granulometry and several geological formations in the southeast of the Netherlands. They found that differences in main and trace elements within and between Dutch formations are mainly related to sorting processes and provenance, causing variation in the sediment mineralogy. Huisman (1997) sampled the Early and Middle Pleistocene Tegelen and Kedichem Formations (Rhine and Meuse deltaic deposits) from the subsurface of the southern Netherlands. He reconstructed provenance-related mineralogical changes and additionally found that syn- and post-depositional diagenetic processes can affect the contents of $\mathrm{Fe}_{2} \mathrm{O}_{3}, \mathrm{MnO}$, $\mathrm{P}_{2} \mathrm{O}_{5}$ and associated trace elements like $\mathrm{As}, \mathrm{Ba}, \mathrm{Ni}, \mathrm{Pb}$ and $\mathrm{Zn}$. Van der Sluys et al. (1997), Swennen et al. (1997) and Swennen \& Van der Sluys (1998a,b) completed the Meuse data set by sampling Holocene overbank sediments at the surface and at depth to assess geochemical baseline data for all major and minor Meuse tributaries in the Ardennes low-mountain range in Belgium. They focused on provenance characteristics and the $<125 \mu \mathrm{m}$ fraction of lithologically homogeneous overbank profiles. Therefore, they only sampled the tributaries and not the Meuse itself, and they paid less attention to granulometric differences.

The tributary source catchments and their related sediment supplies show a diversity of provenance characteristics and obviously differ geochemically from the sediments of the main river. For environmental research on Dutch Meuse sediments, however, it is essential to have data on the main 'Meuse mixed composition' itself. It is the purpose of the present contribution to characterise the natural compositional variation of Late Weichselian and Early Holocene fine-grained Meuse sediments in relation to its granulometry. We report on the results of a bulk geochemical and granulometric research of 636 samples taken from the infillings of main residual Meuse channels. After abandonment due to river-valley incision or morphodynamic cut-off processes, the inactive residual channels provided ideal low-energy environments to act as natural sediment traps for the suspended load fraction passing by during floods. During flooding events, a large number of sediment sources in a variety of tributary catchments supply eroded material in the form of suspended load to the main river. Part of the suspended load stays behind in the residual channel sediment traps. As such, the silty to clayey residual channel infillings can be regarded as the unconsolidated fluvial equivalents of floodplain overbank profiles (Ottesen et al., 1989). The samples taken from fine-grained residual channel infillings therefore reflect the natural compositional variation of the suspended load of the Meuse for a record of flooding events. Special attention is given to the granulometry as well as to the interaction between gyttja/ organic matter characteristics and trace elements. Finally, some time-composition relationships are discussed.

\section{Geological setting}

The natural background values of major and trace elements of present-day Meuse suspended-load deposits should be based on unpolluted fine-grained sediments with a pure Meuse provenance, i.e. without admixture of Rhine sediments. Furthermore, the sampled sediments should have a composition comparable to the present-day suspension load, implying that diagenesis or pedogenesis should not have modified their composition on geological time scales. The sediments of the upper Kreftenheye Formation and Betuwe Formation in central and northern Limburg (the Netherlands) that were deposited in residual channels fulfil these requirements (Fig. 1). They have a pure Meuse origin and they are unlikely to have suffered from post-depositional alteration because they are still unconsolidated.

The earliest gravel deposits of the Kreftenheye Formation date from the Saalian glacial that started some $200 \mathrm{ka}$ ago, whereas the upper Kreftenheye Formation was deposited during the Late Weichselian and Early Holocene (Doppert et al., 1975; Törnqvist et al., 1993). The drainage area of the Meuse has remained essentially unchanged during the last $250 \mathrm{ka}$ (Bustamante, 1976, Van den Berg, 1996), excluding effects of large-scale provenance changes on bulk geochemistry, as have been described for the Rhine system (Huisman, 1997).

At the climatic transition from the Late Weichselian to the Holocene (Late Glacial, about 13 to $9 \mathrm{ka}$ ago), the Meuse progressively lowered its floodplain and 
changed from a braiding multi-channel into a meandering single-channel river (Berendsen et al., 1995; Kasse et al., 1995; Huisink, 1997; Tebbens et al., 1999). Consequently, fine-grained overbank sedimentation started in the Weichselian Late Glacial to cover the Pleniglacial gravels and coarse sands with a loam bed (Makaske \& Nap, 1995). Törnqvist et al. (1993) thoroughly described these overbank deposits and their related clayey, silty and gyttja residual channel infillings and defined them as the Wijchen Member of the Kreftenheye Formation. The Holocene deposits should formally be attributed to the Betuwe Formation (Doppert et al., 1975).

\section{Sampling}

We took some 640 bulk samples at 33 sites (Fig.1) in a currently net depositional $40 \mathrm{~km}$ floodplain stretch of the Meuse, which integrates the combined provenance and sorting effects of a drainage area of $33,000 \mathrm{~km}^{2}$. They are, as a consequence, natural composite samples of the floodplain sample type and are significant at a continental or global scale (Darnley et al., 1995).
The samples originate from largely reduced, unconsolidated sediments (unripened in soil-science terminology) that have been deposited in several residual channels during the last 13,000 years. The residual channel infillings offered wide dating possibilities via intercalated peat and gyttjas (Fig. 2) and enabled sampling of indisputable pre-industrial unpolluted sediments. For details on the sampling sites, ${ }^{14} \mathrm{C}$ dates and morphodynamic aspects of river incision and channel development, we refer to Tebbens et al. (1999).

The sampling strategy and number of samples virtually cover the whole range of possible textures and lateral and downstream variation within the Meuse sediments of the upper Kreftenheye and Betuwe Formations, ensuring a very high regional representativity. For comparison with geochemical baseline data, we note that preferably unconsolidated residual channel infillings under reduced conditions were sampled, instead of regolith or alluvial overbank A- and C-soilhorizon samples. We even avoided soil horizons particularly, to prevent post-depositional overprinting effects owing to recent soil formation or anthropogenic pollution to show up in the dataset. The minimum

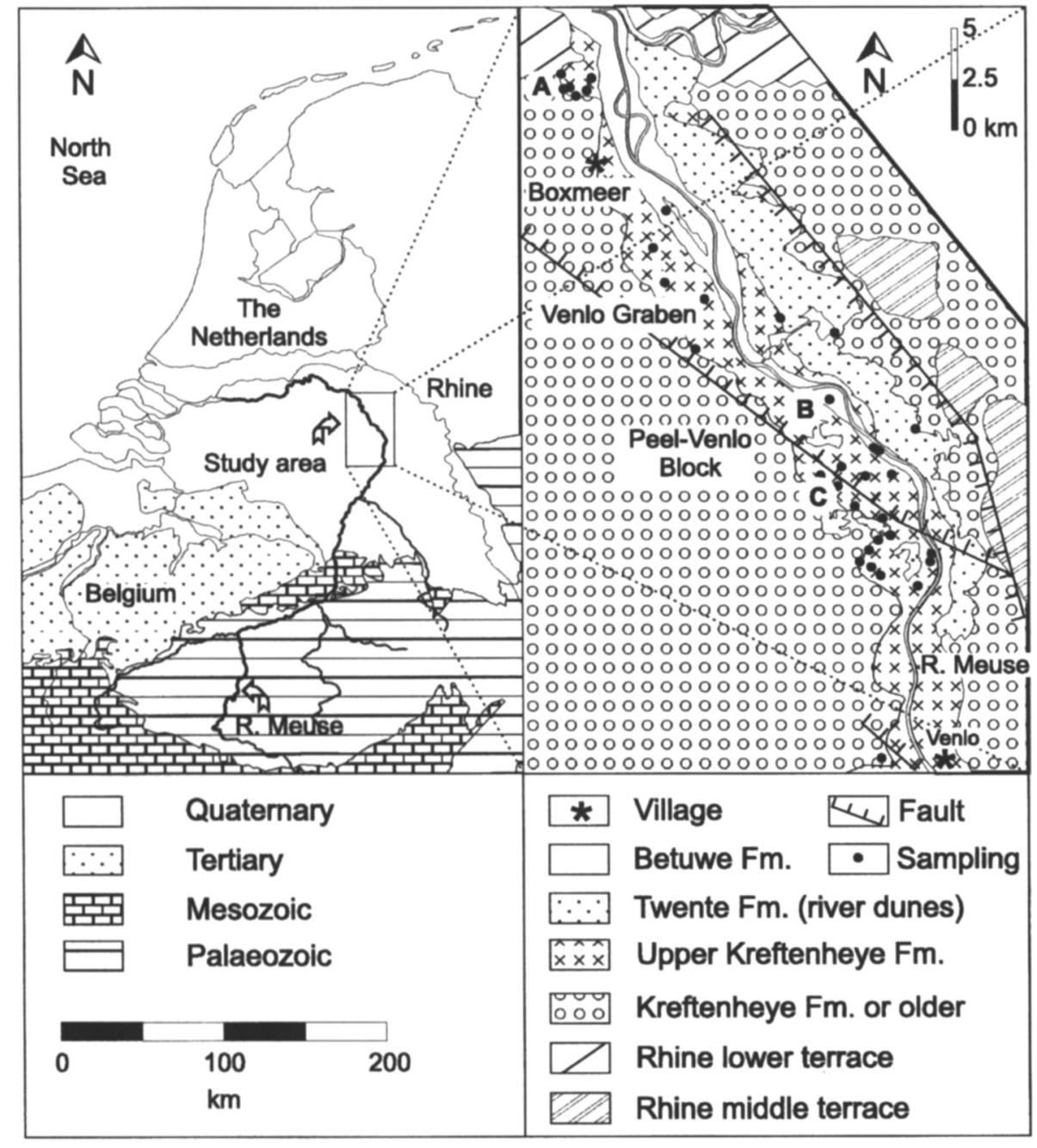

Fig. 1. Major geological and chronostratigraphical units in the Meuse drainage area (left) and the extent of fluvial and eolian deposits in the study area (right). Samples were taken from residual channel infillings (Kreftenheye and Betuwe Formations). A, B and C indicate the sampling sites of vertical profiles in Figs. 2 and 8. 


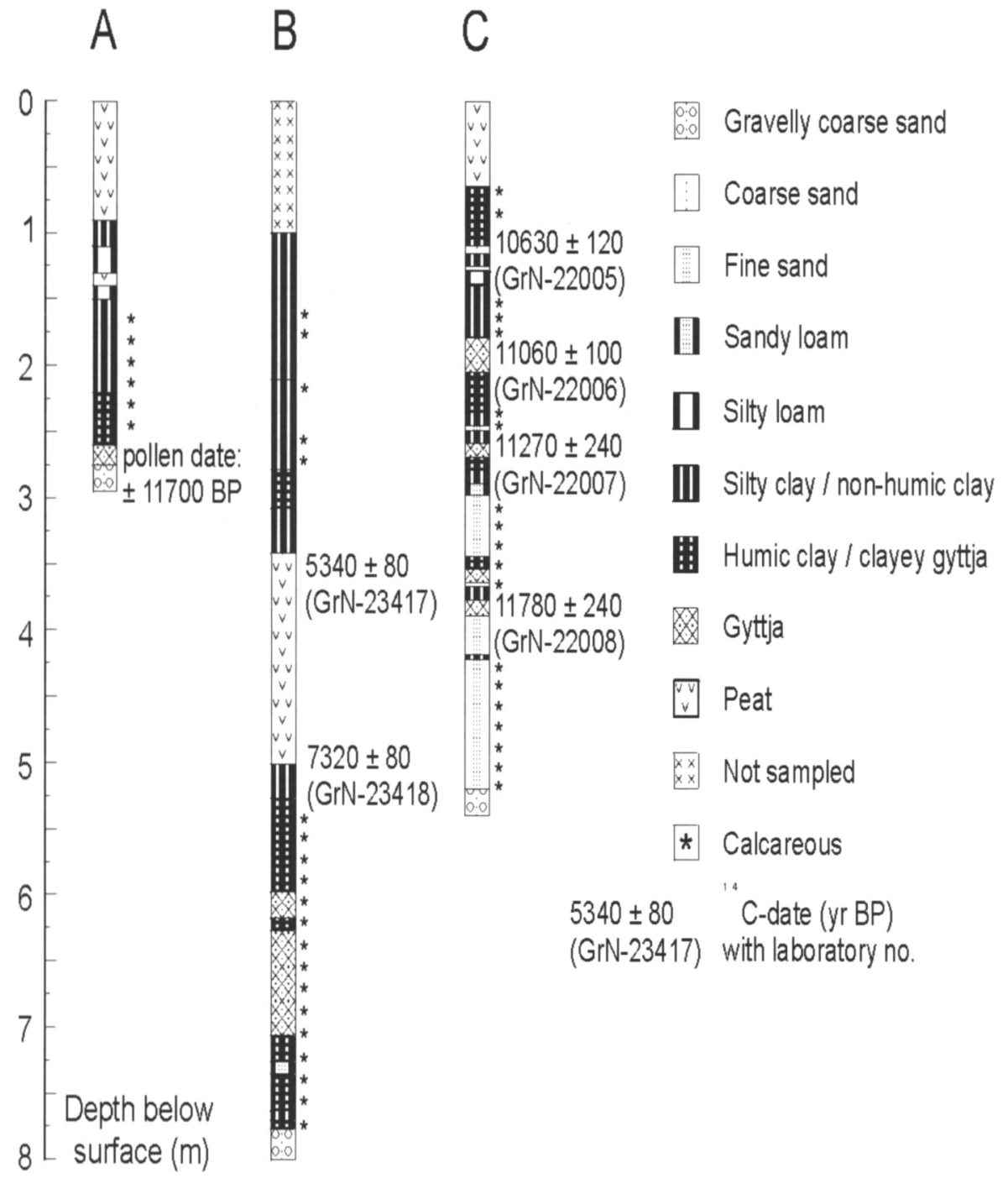

Fig. 2. The vertical profiles of sampling sites A (Beugen), B (Blitterswijck) and $\mathrm{C}$ (Keuter), showing changes in lithology and abundant dating possibilities on gyttja and peat intervals. Sites are indicated on Figure 1. Figure 8 presents the corresponding data on a selection of main and trace elements.

sample depth was $0.3 \mathrm{~m}$, and the maximum depth was $7.7 \mathrm{~m}$ below ground surface. Fluvio-eolian sands in the sand pits at Grubbenvorst and Panheel (not on map) could only be sampled above the groundwater table, however. Bulk clays and silts were sampled per lithological unit or every $10 \mathrm{~cm}$ in case of layers thicker than $10 \mathrm{~cm}$; sands were sampled per lithological unit to evaluate the influence of admixture of sandsized minerals on the bulk geochemistry of the sediments.

\section{Bulk geochemical and granulometric measure- ments}

In the laboratory, the samples were dried at $60^{\circ} \mathrm{C}$, gently disaggregated in a china mortar, dry sieved and finally homogenised. Utmost care was taken not to lose the finer or organic fractions. The fraction $<2000$ $\mu \mathrm{m}$ was analysed both for bulk geochemistry (X-ray fluorescence spectometry, XRF) and for granulometry (laser diffraction). Bulk geochemical analysis enables rapid analysis of a large number of samples and yields additional information on rock fragments, fine fractions and diagenetic processes normally not studied in mineralogical studies (Kroonenberg, 1990, 1994; Moura \& Kroonenberg, 1990).

For the XRF measurements, a subsample of about $4 \mathrm{~g}$ was milled (and homogenised again) for five minutes in a Fritsch ball mill apparatus with 'Sialon' milling material (hardness about 9-10 on Mohs' scale). Subsequently, $0.600 \mathrm{~g}$ of milled sample was ignited with $2.400 \mathrm{~g} \mathrm{Li}$-tetraborate at $1800^{\circ} \mathrm{C}$ to form a 23-mm diameter glass bead. The oxidation of organic matter and volatilisation of (1) crystal water from clay minerals, (2) $\mathrm{CO}_{2}$ from carbonates, and (3) $\mathrm{SO}_{2}$ from sulphates at this high temperature yield a loss in sample weight. This loss represents - and will be referred to in the following - as the 'loss on ignition' (LOI). A number of 636 samples have been measured using a Philips PW-1404 assembly and international standards. The contents of $\mathrm{SiO}_{2}, \mathrm{TiO}_{2}, \mathrm{Al}_{2} \mathrm{O}_{3}, \mathrm{Fe}_{2} \mathrm{O}_{3}$, $\mathrm{MgO}, \mathrm{MnO}, \mathrm{CaO}, \mathrm{Na}_{2} \mathrm{O}, \mathrm{K}_{2} \mathrm{O}$ and $\mathrm{P}_{2} \mathrm{O}_{5}$ have been measured with a $\mathrm{Sc}$ tube. The trace elements $\mathrm{Ba}, \mathrm{Ce}$, $\mathrm{Co}, \mathrm{Cr}, \mathrm{Cs}, \mathrm{Cu}, \mathrm{Ga}, \mathrm{La}, \mathrm{Nb}, \mathrm{Nd}, \mathrm{Ni}, \mathrm{Pb}, \mathrm{Rb}, \mathrm{Sr}, \mathrm{Th}$, 
$\mathrm{V}, \mathrm{Y}, \mathrm{Zn}$ and $\mathrm{Zr}$ were measured with a $\mathrm{Rh}$ tube.

Granulometric analyses were undertaken on a 1 to $20 \mathrm{~g}$ (depending on texture) sample after a $30 \% \mathrm{H}_{2} \mathrm{O}_{2}$ pretreatment. The samples were not washed, to retain the fine fractions. In case of samples exceptionally rich in organic matter (e.g., gyttjas), however, this yielded too high values for the $0-20 \mu \mathrm{m}$ fraction, due to incomplete destruction of fine organic particles. Sodium pyrophosphate was added to prevent flocculation of the clay fraction. Laser diffraction was performed at $10 \%$ sample obscuration using a Coulter LS230 Grain Sizer with a range of 0.04 to $2000 \mu \mathrm{m}$ and software version 2.05 (Buurman et al., 1997). Additional information on clay geochemistry and X-ray diffraction (XRD) measurements of a selection of 60 clay fractions can be found in Tebbens et al. (1998).

\section{Results}

Covarying bulk geochemical and granulometric data clearly demonstrate a strong dependency of elemental concentrations on the sample granulometry. The clay and fine silt granulometric fractions concentrate Albearing phyllosilicates (clay minerals and micas) (Van den Broek \& Van der Marel, 1980; Moura \& Kroonenberg, 1990; Huisman, 1997). This enables us to infer a high clay and fine silt content geochemically from high $\mathrm{Al}_{2} \mathrm{O}_{3}$ percentages in bulk samples (Tebbens et al., 1998; Huisman \& Kiden, 1998). Sandy samples (defined as samples with $<30 \% \quad 0-20 \mu \mathrm{m}$ fraction) typically contain $>80 \% \mathrm{SiO}_{2}$ (Fig. 3), whereas clayey and silty samples $(>30 \%$ of the $0-20 \mu \mathrm{m}$ fraction) generally have $<80 \% \mathrm{SiO}_{2}$ and $>10 \% \mathrm{Al}_{2} \mathrm{O}_{3}$. $\mathrm{Al}_{2} \mathrm{O}_{3}$ strongly correlates $(\mathrm{r}=0.88)$ to the $0-20 \mu \mathrm{m}$ (clay and fine silt) granulometric fraction, while $\mathrm{SiO}_{2}$ behaves inversely $(r=-0.82)$. Samples deviating from these linear trends are rich in organic matter and have $>10 \%$ LOI. Clayey bulk samples are systematically higher in $\mathrm{TiO}_{2}, \mathrm{~K}_{2} \mathrm{O}, \mathrm{MgO}, \mathrm{Fe}_{2} \mathrm{O}_{3}$, LOI and several trace elements such as $\mathrm{Rb}, \mathrm{V}$ and $\mathrm{Cr}$ (Figs. 4, 5a,b).

As a first statistical reconnaissance study, a principal component analysis was performed on the data-

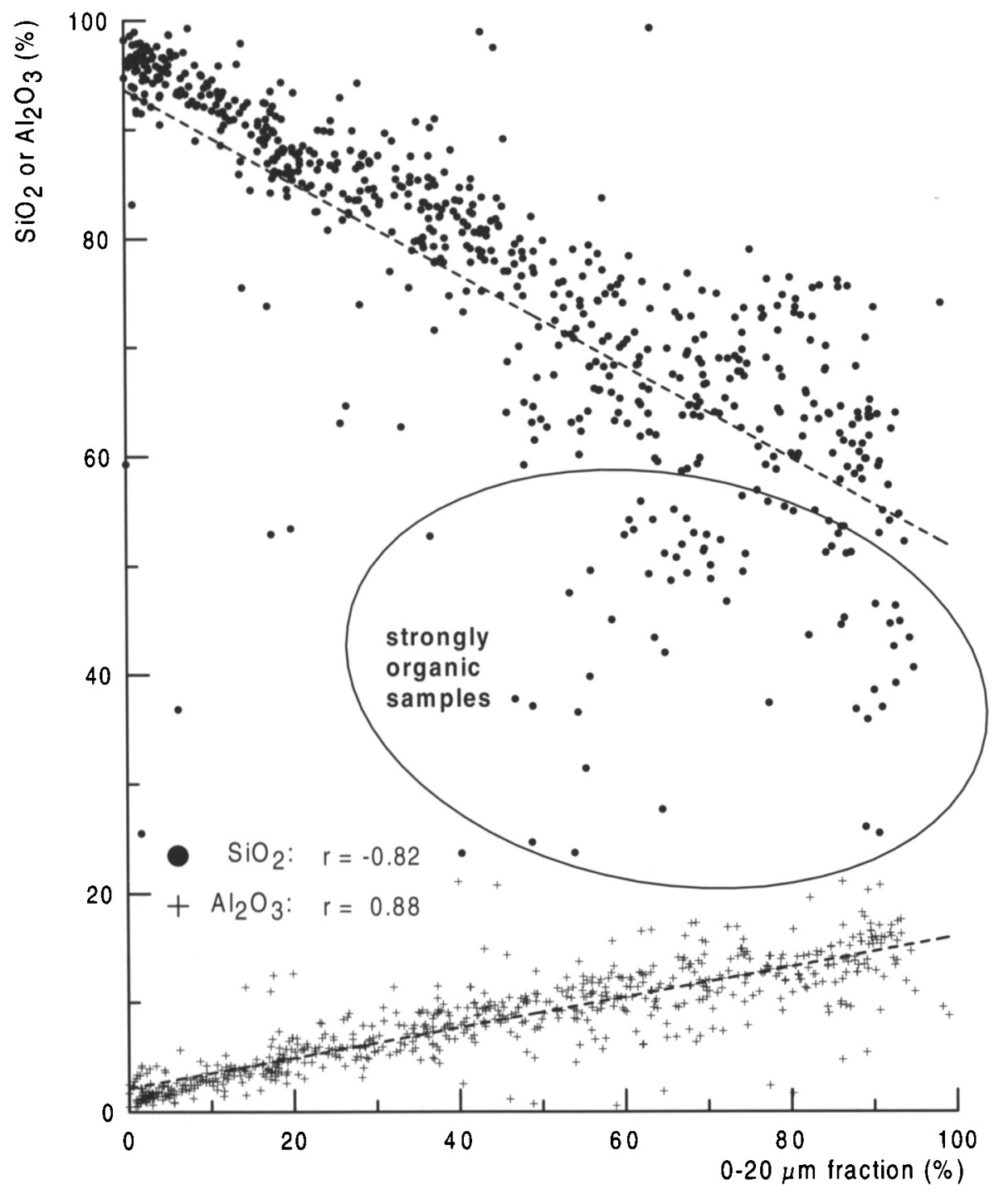

Fig. 3. The relationship between the 0 $20 \mu \mathrm{m}$ fraction (determined by laser granulometry) and the contents of $\mathrm{SiO}_{2}$ (dots) and $\mathrm{Al}_{2} \mathrm{O}_{3}$ (crosses). Samples deviating from linear trends (e.g., squares within ellipse) have high organic-matter contents. 
set, containing both the bulk geochemical and the granulometric data (Table 1). Analyses below detection limits were labelled zero, and have been included in the statistical analysis. The trace elements $C s$ and Th were not included because too many samples were reported below detection limits. Cu has been left out, too, for contamination during sieving over copper mesh was suspected. The analysis yielded four major factors with strongly covarying variables. A mineralogical interpretation of the factors yielded a clay and fine silt/phyllosilicate factor (factor 1), a coarse silt/heavy-mineral factor (factor 2), a gyttja/ siderite factor (factor 3) and a calcium-carbonate factor (factor 4).

\section{Clay and fine silt/phyllosilicate factor}

The 0-20 $\mu \mathrm{m}$ fraction (CLFSILT in Table 1), the major constituents $\mathrm{Al}_{2} \mathrm{O}_{3}, \mathrm{~K}_{2} \mathrm{O}, \mathrm{MgO}, \mathrm{TiO}_{2}$, and the trace metals $\mathrm{V}, \mathrm{Ga}, \mathrm{Rb}, \mathrm{Ba}, \mathrm{Cr}, \mathrm{Ce}, \mathrm{Zn}, \mathrm{Ni}$ and $\mathrm{La}$, are strongly interrelated. The assemblage is extracted as a clay and fine-silt factor with factor loadings $>0.8$ for the individual elements. Obviously, this factor mainly represents phyllosilicates in the clay and fine-silt size fractions (Van der Broek \& Van der Marel, 1964, 1980). $\mathrm{Nd}$ and Co have a lower factor loading (>0.7) to the clay and fine-silt fraction. $\mathrm{Pb}$ was not correlated to any of the factors, due to some anomalous outliers in the dataset (see below). After removing these outliers for $\mathrm{Pb}$, a relatively good correlation with the

Table 1. Bulk sediment geochemical communalities and factor loadings (after Varimax rotation) for the elements of the first four factors with eigenvalues $>1$ (factor loadings $<0.5$ have been suppressed). The eigenvalue (EV) and the percentage of trace (PT) are indicated per factor. The factor loadings can be considered as the correlation coefficient between the extracted factor and the major constituent or trace element. CLFSILT $=$ clay and fine-silt fraction $(0-20 \mu \mathrm{m})$. CSILT $=$ coarse-silt fraction $(20-80 \mu \mathrm{m})$. FSAND $=$ fine-sand fraction $(80-210 \mu \mathrm{m})$. CSAND $=$ coarse-sand fraction $(210-2000 \mu \mathrm{m})$. LOI $=$ loss on ignition.

\begin{tabular}{|c|c|c|c|c|c|}
\hline variable & communality & $\begin{array}{l}\text { factor } 1 \\
\text { EV: } 17.1 \\
\text { PT: } 55.2 \%\end{array}$ & $\begin{array}{l}\text { factor } 2 \\
\text { EV: } 4.5 \\
\text { PT: } 14.5 \%\end{array}$ & $\begin{array}{l}\text { factor } 3 \\
\text { EV: } 2.5 \\
\text { PT: } 8.2 \%\end{array}$ & $\begin{array}{l}\text { factor } 4 \\
\text { EV: } 1.2 \\
\text { PT: } 3.8 \%\end{array}$ \\
\hline $\mathrm{Al}_{2} \mathrm{O}_{3}$ & 0.97 & 0.97 & & & \\
\hline V & 0.96 & 0.97 & & & \\
\hline $\mathrm{Ga}$ & 0.95 & 0.97 & & & \\
\hline $\mathrm{Rb}$ & 0.90 & 0.96 & & & \\
\hline $\mathrm{Ba}$ & 0.88 & 0.92 & & & \\
\hline $\mathrm{Cr}$ & 0.96 & 0.92 & & & \\
\hline $\mathrm{K}_{2} \mathrm{O}$ & 0.93 & 0.90 & & & \\
\hline $\mathrm{Ce}$ & 0.90 & 0.89 & & & \\
\hline $\mathrm{Zn}$ & 0.85 & 0.88 & & & \\
\hline $\mathrm{Ni}$ & 0.82 & 0.87 & & & \\
\hline CLFSILT & 0.91 & 0.86 & & & \\
\hline $\mathrm{TiO}_{2}$ & 0.96 & 0.84 & & & \\
\hline $\mathrm{La}$ & 0.77 & 0.84 & & & \\
\hline $\mathrm{MgO}$ & 0.92 & 0.83 & & & \\
\hline $\mathrm{Nd}$ & 0.94 & 0.73 & & & \\
\hline Co & 0.66 & 0.72 & & & \\
\hline FSAND & 0.68 & -0.67 & & & \\
\hline $\mathrm{Pb}$ & 0.19 & see text & & & \\
\hline $\mathrm{Zr}$ & 0.87 & & 0.89 & & \\
\hline CSILT & 0.76 & & 0.80 & & \\
\hline $\mathrm{Nb}$ & 0.81 & & 0.73 & & \\
\hline CSAND & 0.86 & -0.57 & -0.62 & & \\
\hline $\mathrm{Y}$ & 0.65 & 0.53 & 0.60 & & \\
\hline $\mathrm{Na}_{2} \mathrm{O}$ & 0.44 & & 0.50 & & \\
\hline $\mathrm{Fe}_{2} \mathrm{O}_{3}$ & 0.87 & & & 0.92 & \\
\hline $\mathrm{P}_{2} \mathrm{O}_{5}$ & 0.75 & & & 0.85 & \\
\hline $\mathrm{MnO}$ & 0.73 & & & 0.77 & \\
\hline $\mathrm{SiO}_{2}$ & 0.95 & -0.59 & & -0.73 & \\
\hline LOI & 0.68 & & & 0.66 & \\
\hline $\mathrm{CaO}$ & 0.86 & & & & 0.78 \\
\hline $\mathrm{Sr}$ & 0.93 & 0.62 & & & 0.64 \\
\hline
\end{tabular}


clay and fine-silt fraction or $\mathrm{Al}_{2} \mathrm{O}_{3}$ content $(\mathrm{r}=0.71)$ is found. The negative loadings for $\mathrm{SiO}_{2}$ and the fine $(80-210 \mu \mathrm{m})$ and coarse sand $(210-2000 \mu \mathrm{m})$ fractions stress the compositional difference between the 0-20 $\mu \mathrm{m}$ rich samples that are poor in quartz and the coarser grain-size classes rich in quartz (Van der Broek \& Van der Marel, 1980).

Figure 4 shows the scatterplots of $\mathrm{Al}_{2} \mathrm{O}_{3}$ content (considered here to represent the clay and fine silt fraction) versus $\mathrm{K}_{2} \mathrm{O}, \mathrm{MgO}, \mathrm{TiO}_{2}$ and $\mathrm{Fe}_{2} \mathrm{O}_{3}$. Samples from strongly organic peat or purely organic gyttjas have been omitted, since they do not represent the detrital clastic suspension load of the main river. The main elements $\mathrm{K}_{2} \mathrm{O}, \mathrm{MgO}$ and $\mathrm{TiO}_{2}$ are strongly positive linear related (Table 2) to the $\mathrm{Al}_{2} \mathrm{O}_{3}$ content. Note that Holocene samples show considerable com- positional variability and behave differently from Late Glacial samples in the clay and fine-silt granulometrical range. Clayey samples also contain more $\mathrm{Fe}_{2} \mathrm{O}_{3}$, and clastic clayey gyttja samples are even richer due to the presence of siderite and vivianite (see below). Similarly, most trace elements show strong relationships to the $\mathrm{Al}_{2} \mathrm{O}_{3}$ content (Fig. 5), permitting the conclusion that they are mainly built in into the phyllosilicate lattices or adsorbed on their reactive surfaces. The $\mathrm{Al}_{2} \mathrm{O}_{3} / \mathrm{Rb}$ plot (Fig. 5) and the plots of $\mathrm{K}_{2} \mathrm{O}$ versus $\mathrm{Ba}, \mathrm{Cr}, \mathrm{Rb}$ and $\mathrm{V}$ (Fig. 6) again reveal differences between Pleniglacial/Late Glacial and Holocene samples. These differences are similar to the aforementioned differences found for the same sample groups in the $\mathrm{Al}_{2} \mathrm{O}_{3} / \mathrm{K}_{2} \mathrm{O}$ and $\mathrm{Al}_{2} \mathrm{O}_{3} / \mathrm{MgO}$ plots (Fig. 4).
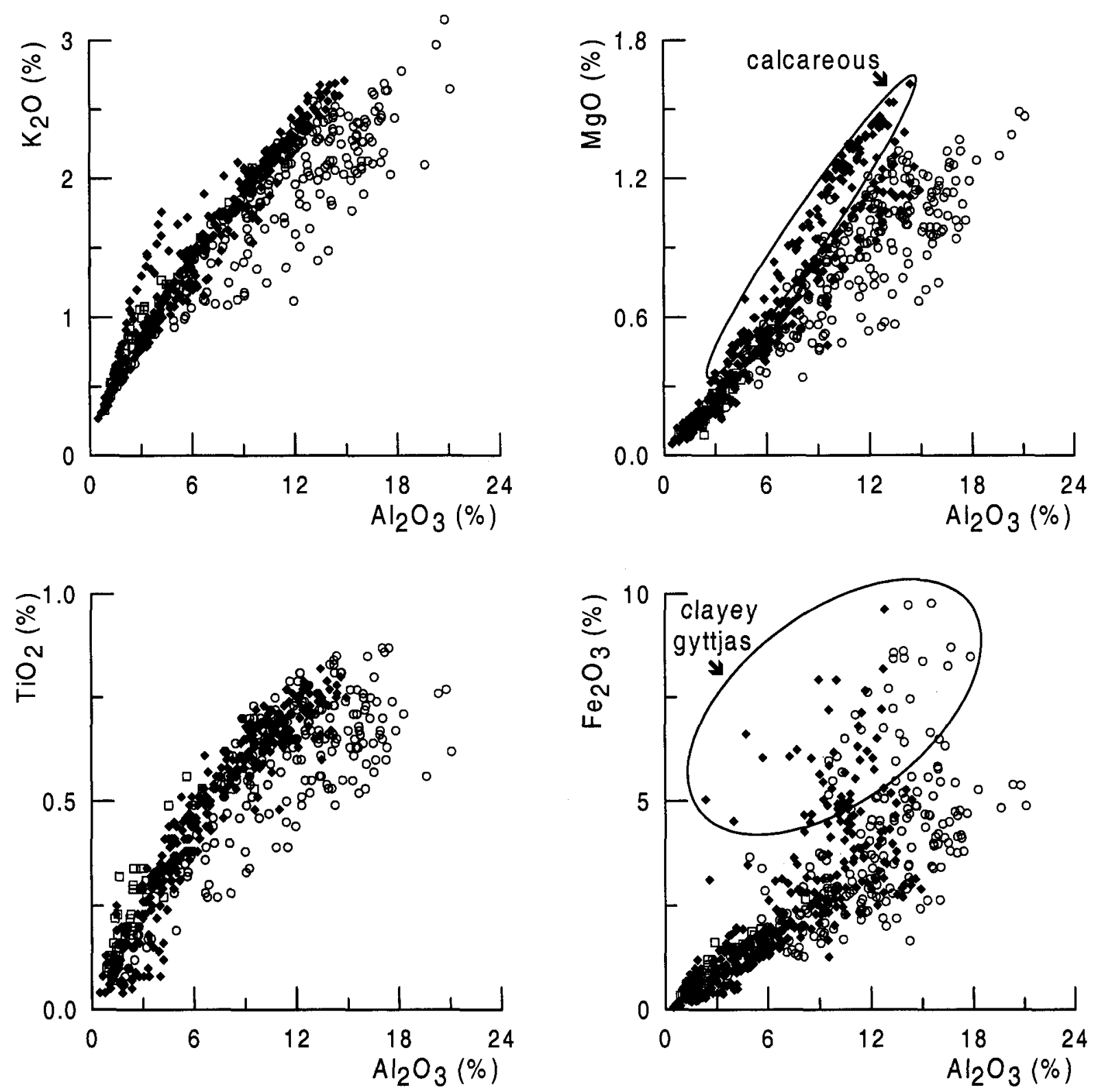

Fig. 4. The relationship between the contents of $\mathrm{Al}_{2} \mathrm{O}_{3}$ and $\mathrm{K}_{2} \mathrm{O}, \mathrm{MgO}, \mathrm{TiO}_{2}$ and $\mathrm{Fe}_{2} \mathrm{O}_{3}$ for 636 bulk sediment samples of Pleniglacial, Late $\mathrm{Glacial}$ and Holocene age. Note the systematic shift towards lower $\mathrm{K}_{2} \mathrm{O}, \mathrm{MgO}$ and $\mathrm{TiO}_{2}$ values for Holocene samples. 

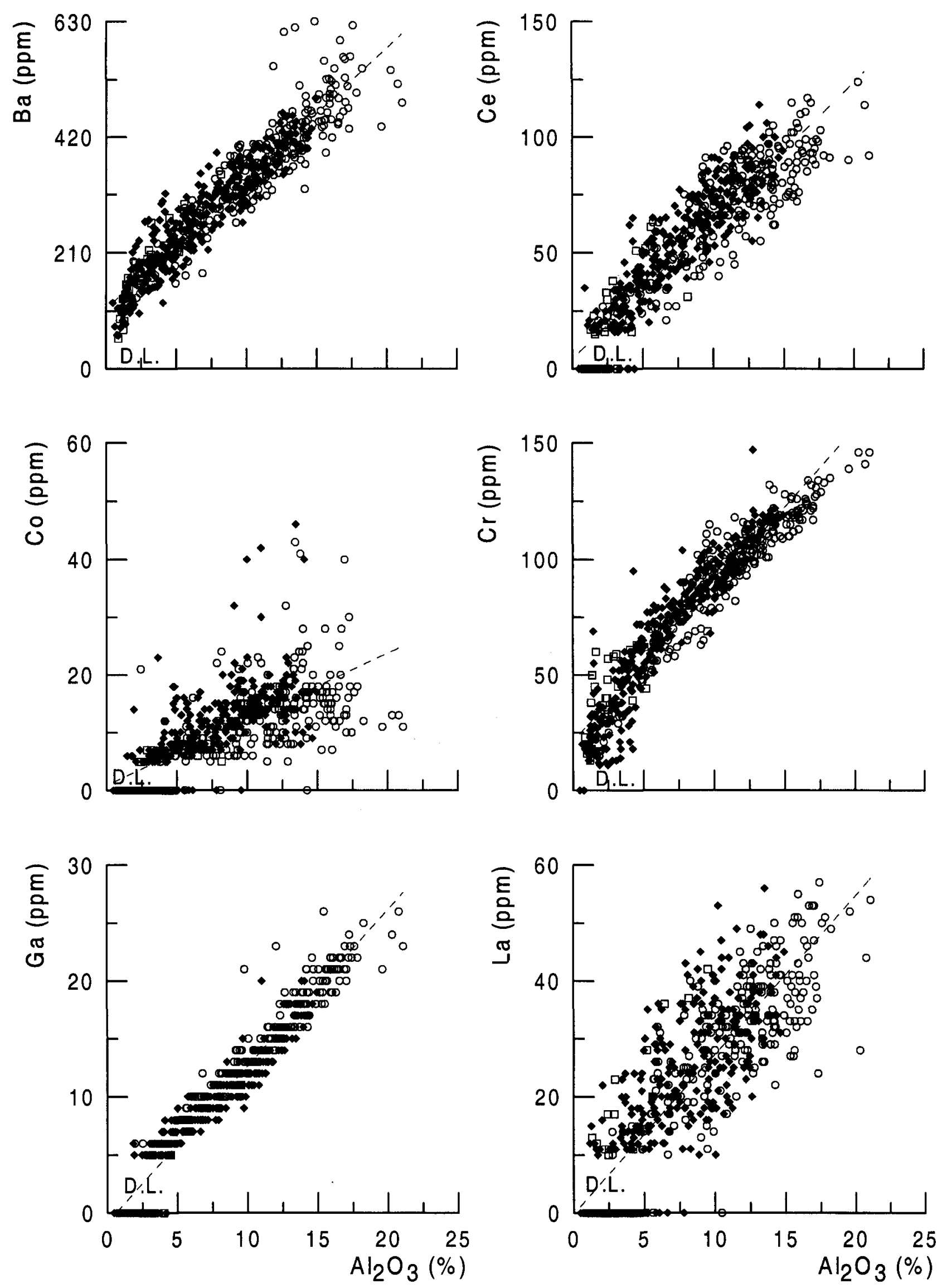

Fig. 5 (pp. 398-399). The relationship between the contents of $\mathrm{Al}_{2} \mathrm{O}_{3}$ and trace elements for bulk sediment samples. Some extreme outliers in the $\mathrm{Pb}$ and $\mathrm{Zn}$ graphs have been omitted (see text). D.L. = Detection limit. Symbol legend: see Figure 4 . Data on the linear fits are listed in Table 2. 

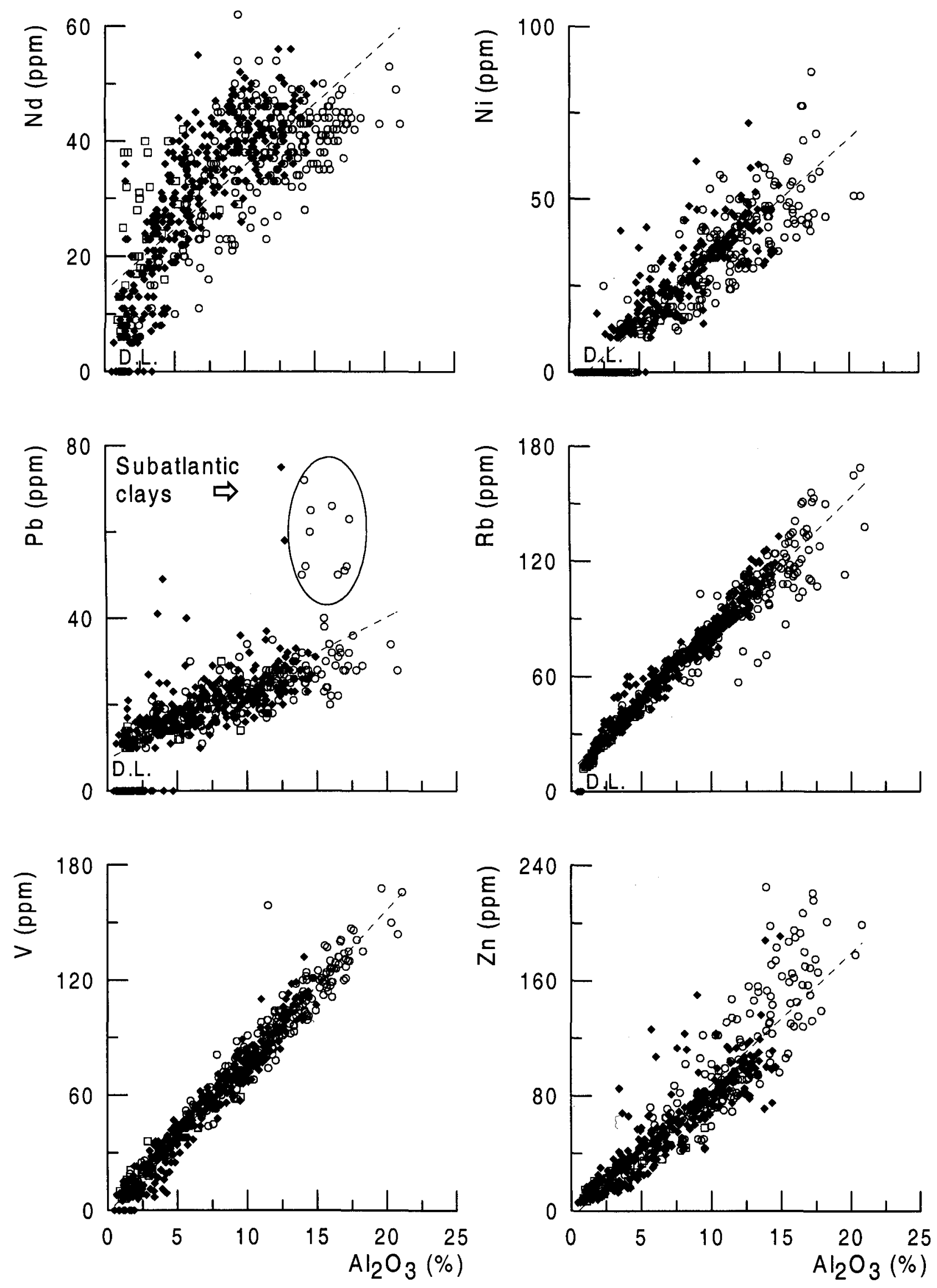

Fig. 5 (continued). 
Table 2. Multiple linear regression models for a selection of major and trace elements for the whole dataset. Models are of the form $\mathbf{Y}=\mathbf{a} \cdot$ $\mathrm{Al}_{2} \mathrm{O}_{3}+\mathbf{b} \cdot \mathrm{Fe}_{2} \mathrm{O}_{3}+\mathbf{c} \cdot \mathrm{CaO}+\mathbf{d}$, with $\mathrm{Y}$ being the predicted major constituent (in mass \%) or trace elements (in ppm), and $\mathrm{Al}_{2} \mathrm{O}_{3}, \mathrm{Fe}_{2} \mathrm{O}_{3}$, and $\mathrm{CaO}$ also in mass \%. $\mathrm{R}^{2}$ is the goodness of fit, figures in bold are significant at the $95 \%$ confidence level; $n$ is the number of observations. For calculation of $\mathrm{Co}, \mathrm{Ni}, \mathrm{Pb}$ and $\mathrm{Zn}, 13$ samples showing anomalies or extreme outliers have been omitted (see text).

\begin{tabular}{|c|c|c|c|c|c|c|}
\hline $\mathbf{Y}$ & $\mathbf{a}$ & $\mathrm{b}$ & $\mathrm{c}$ & $\mathrm{d}$ & $\mathbf{R}^{2}$ & $\mathrm{n}$ \\
\hline $\mathrm{K}_{2} \mathrm{O}$ (all) & 0.1300 & -0.0113 & 0.0207 & 0.5454 & 0.86 & 636 \\
\hline $\mathrm{K}_{2} \mathrm{O}$ (Pleniglacial) & 0.2145 & -0.1329 & 0.7669 & 0.2893 & 0.97 & 38 \\
\hline $\mathrm{K}_{2} \mathrm{O}$ (Iate Glacial) & 0.1668 & -0.0101 & -0.0054 & 0.4053 & 0.95 & 372 \\
\hline $\mathrm{K}_{2} \mathrm{O}$ (Holocene) & 0.1095 & -0.0074 & 0.0598 & 0.6187 & 0.77 & 226 \\
\hline $\mathrm{MgO}$ (all) & 0.0728 & 0.0020 & 0.0401 & 0.0472 & 0.86 & 636 \\
\hline MgO (Pleniglacial) & 0.0832 & 0.0045 & -0.2831 & -0.0101 & 0.97 & 38 \\
\hline MgO (Late Glacial) & 0.0975 & 0.0032 & 0.0326 & -0.0500 & 0.95 & 372 \\
\hline MgO (Holocene) & 0.0601 & 0.0041 & 0.0620 & 0.0998 & 0.80 & 226 \\
\hline $\mathrm{TiO}_{2}($ all $)$ & 0.0426 & -0.0037 & 0.0065 & 0.1376 & 0.79 & 636 \\
\hline $\mathrm{TiO}_{2}$ (Pleniglacial) & -0.0379 & 0.2077 & 1.0347 & 0.0262 & 0.88 & 38 \\
\hline $\mathrm{TiO}_{2}$ (Late Glacial) & 0.0564 & -0.0029 & -0.0004 & 0.0718 & 0.91 & 372 \\
\hline $\mathrm{TiO}_{2}$ (Holocene) & 0.0325 & 0.0017 & -0.0055 & 0.2070 & 0.60 & 226 \\
\hline $\mathrm{Ba}$ & 24.0455 & -0.5776 & -3.4005 & 110.57 & 0.89 & 636 \\
\hline $\mathrm{Ce}$ & 5.9904 & 0.0662 & -0.1190 & 4.04 & 0.83 & 636 \\
\hline Co & 1.0492 & 0.2152 & 0.1684 & 0.71 & 0.53 & 623 \\
\hline $\mathrm{Cr}$ & 6.7234 & 0.2730 & -0.8947 & 21.50 & 0.90 & 636 \\
\hline Ga & 1.3432 & 0.0736 & -0.2014 & -0.76 & 0.94 & 636 \\
\hline $\mathrm{La}$ & 2.7435 & 0.1159 & -0.1406 & -0.29 & 0.71 & 636 \\
\hline $\mathrm{Nd}$ & 2.2392 & -0.1732 & -0.1081 & 14.05 & 0.59 & 636 \\
\hline $\mathrm{Ni}$ & 3.5159 & 0.4110 & 0.2717 & -4.68 & 0.81 & 623 \\
\hline $\mathrm{Pb}$ & 1.6862 & -0.2942 & -0.3670 & 7.78 & 0.54 & 623 \\
\hline $\mathrm{Rb}$ & 7.2146 & -0.4260 & -0.2230 & 11.71 & 0.83 & 636 \\
\hline $\mathrm{Sr}$ & 4.3123 & -0.8737 & 8.8090 & 23.59 & 0.88 & 636 \\
\hline V & 7.7766 & 0.5764 & -0.8111 & -0.95 & 0.96 & 636 \\
\hline $\mathrm{Zn}$ & 1.7405 & -1.6990 & 0.6546 & 8.44 & 0.79 & 623 \\
\hline
\end{tabular}

Coarse-silt/heavy-mineral factor

The 20-80 $\mu \mathrm{m}$ (coarse silt) fraction, the trace elements $\mathrm{Zr}, \mathrm{Nb}$ and to a lesser extent $\mathrm{Y}$ and $\mathrm{Nd}$, showed highest factor loadings for factor 2. Heavy minerals (like zircon) contain abundant $\mathrm{Zr}, \mathrm{Nb}, \mathrm{Y}$ and $\mathrm{Nd}$ and are concentrated in the silt and finesand fractions (Tebbens et al., 1998). Therefore, we interpret factor 2 as a coarse-silt/heavy-mineral factor. Swennen \& Van der Sluys (1998a,b) additionally mention the concentration of $\mathrm{Ti}, \mathrm{Cr}$ and $\mathrm{Hf}$ in heavy minerals as rutile, ilmenite and chromite, but in the present study, $\mathrm{Ti}$ and $\mathrm{Cr}$ were correlated to the clay factor.

The $20-80 \mu \mathrm{m}$ fraction demonstrates weak positive relationships with considerable scattering to the $\mathrm{Zr}$ $\mathrm{Nb}-\mathrm{Nd}-\mathrm{Y}$ quartet, of which $\mathrm{Zr}$ is shown as an example (Fig. 7). Strongly organic (clayey) gyttja samples are low in detrital heavy minerals and thus are poor in $\mathrm{Zr}, \mathrm{Nb}, \mathrm{Nd}$ and $\mathrm{Y}$. Fine sandy and silty samples are relatively rich in detrital heavy minerals and consequently have higher contents of trace elements. Silty clay samples are richest in $\mathrm{Nd}$ and $\mathrm{Y}$ because of their joint occurrence in coarse-silt-fraction heavy minerals and phyllosilicates.

\section{Gyttja/diagenetic-mineral factor}

The gyttja/siderite factor contains the major components $\mathrm{Fe}_{2} \mathrm{O}_{3}, \mathrm{MnO}, \mathrm{P}_{2} \mathrm{O}_{5}$ and LOI. The $\mathrm{SiO}_{2}$ content relates inversely to this factor. Siderite $\left(\mathrm{FeCO}_{3}\right)$ and vivianite $\left(\mathrm{Fe}_{3}\left(\mathrm{PO}_{4}\right)_{2} \cdot 8 \mathrm{H}_{2} \mathrm{O}\right)$ are characteristic post-depositional early-diagenetic minerals for the anoxic bicarbonate-rich gyttja environment (Curtis, 1995). They are frequently reported in freshwater river fens and peat (Postma, 1982; Huisman, 1997). The presence of both siderite and vivianite in our samples could be established by SEM (scanning electron microscopy) and XRD (Huisman, 1997) and in comparable samples from the same residual Meuse channels (Westerhoff et al., 1990; Walraven et al., in press). Siderite and vivianite raise the contents of $\mathrm{Fe}_{2} \mathrm{O}_{3}, \mathrm{MnO}$ and $\mathrm{P}_{2} \mathrm{O}_{5}$ in pure organic and clayey gyttja samples (see the vertical profiles of Figs. 2 and 8 ) and cause a weak correlation of these major constituents with the $\mathrm{Al}_{2} \mathrm{O}_{3}$ content (e.g. $\mathrm{Fe}_{2} \mathrm{O}_{3}$ : Fig. 4). After omitting the 

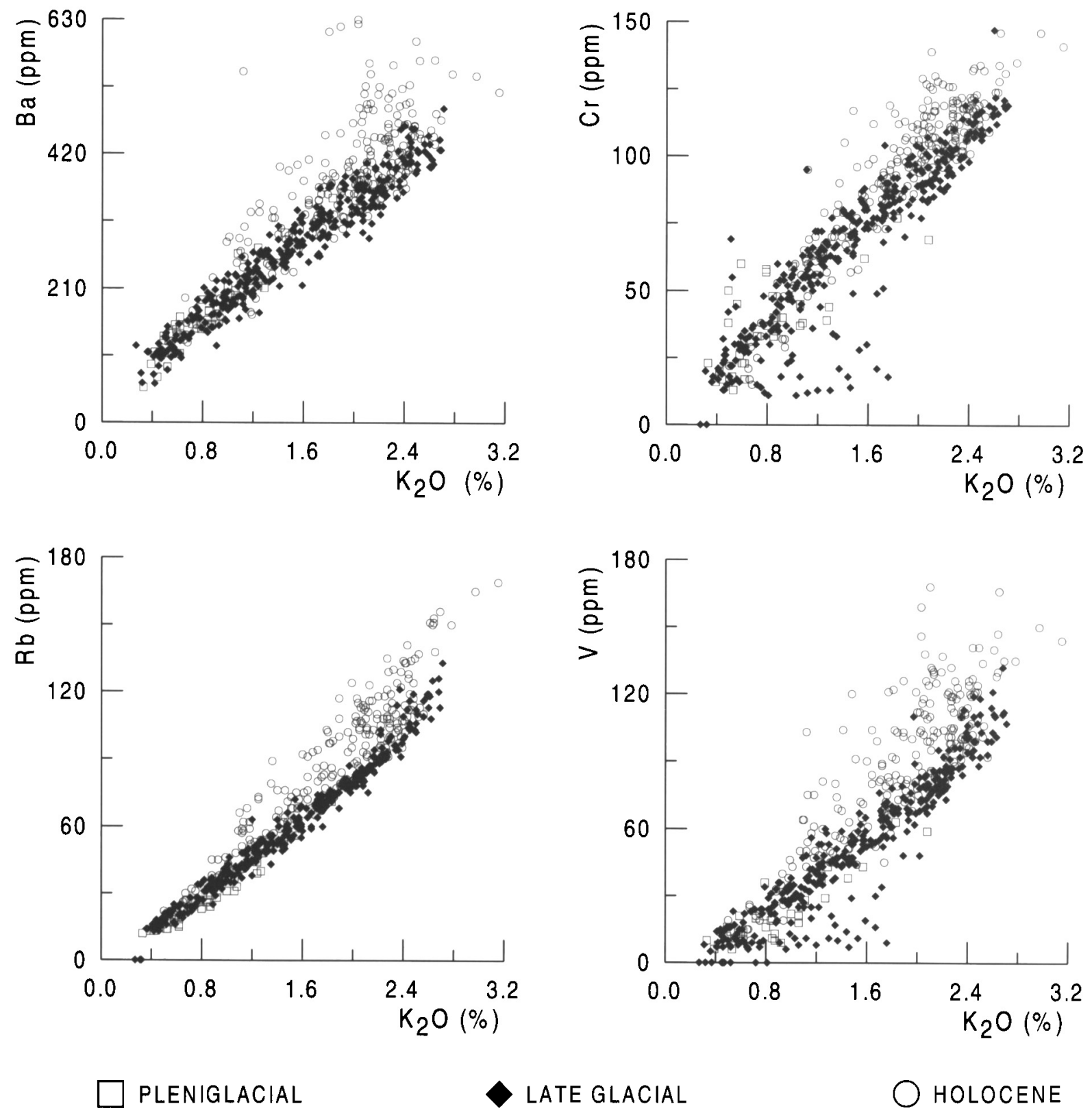

Fig. 6. The relationship between the contents of $\mathrm{K}_{2} \mathrm{O}$ and the trace elements, $\mathrm{Ba}, \mathrm{Cr}, \mathrm{Rb}$ and $\mathrm{V}$, for 636 bulk sediment samples of Pleniglacial, Late Glacial and Holocene age. Note the systematic shift towards higher $\mathrm{Ba}, \mathrm{Cr}, \mathrm{Rb}$ and $\mathrm{V}$ values in Holocene samples.

most gyttja/siderite-rich samples the bivariate correlation improves to $\mathrm{r}=0.76$, with the $\mathrm{Fe}_{2} \mathrm{O}_{3} / \mathrm{Al}_{2} \mathrm{O}_{3}$ ratio more resembling the one in phyllosilicates.

The gyttja/siderite factor did not incorporate trace elements, probably because they are predominantly built in into phyllosilicate lattices. Individual gyttja samples do, however, show a relative enrichment of $\mathrm{Co}, \mathrm{Ni}$ and, notably, $\mathrm{Zn}$. This becomes clear after normalisation by $\mathrm{Al}_{2} \mathrm{O}_{3}$ to account for their natural occurrence in phyllosilicates (Figs. 2 and 8 ). Note that the Holocene gyttja profile (B) shows the highest accumulation in absolute concentrations for $\mathrm{P}_{2} \mathrm{O}_{5}, \mathrm{Co}, \mathrm{Ni}$ and $\mathrm{Zn}$. Post-depositional accumulation of $\mathrm{Co}, \mathrm{Ni}$ and $\mathrm{Zn}$ in gyttja samples causes scattering in the graphs and consequently a less good correlation with the $\mathrm{Al}_{2} \mathrm{O}_{3}$ content. Similar enrichments for the other trace elements were expected in gyttja samples and have been checked, but they were not found.

\section{Calcium-carbonate factor}

$\mathrm{CaO}$ and the trace element $\mathrm{Sr}$ contribute positively to the calcium-carbonate factor. Strongly calcareous samples (samples effervescing with $2-\mathrm{M} \mathrm{HCl}$ and/or containing roughly $>1 \% \mathrm{CaO}$ ) contain about two to three times as much $\mathrm{Sr}$ as non-calcareous samples (not effervescing with $2-\mathrm{M} \mathrm{HCl}$ and/or containing $<1 \% \mathrm{CaO}$ ) with comparable clay and fine-silt content (Fig. 9). Sr is not only related to the calcium-carbon- 


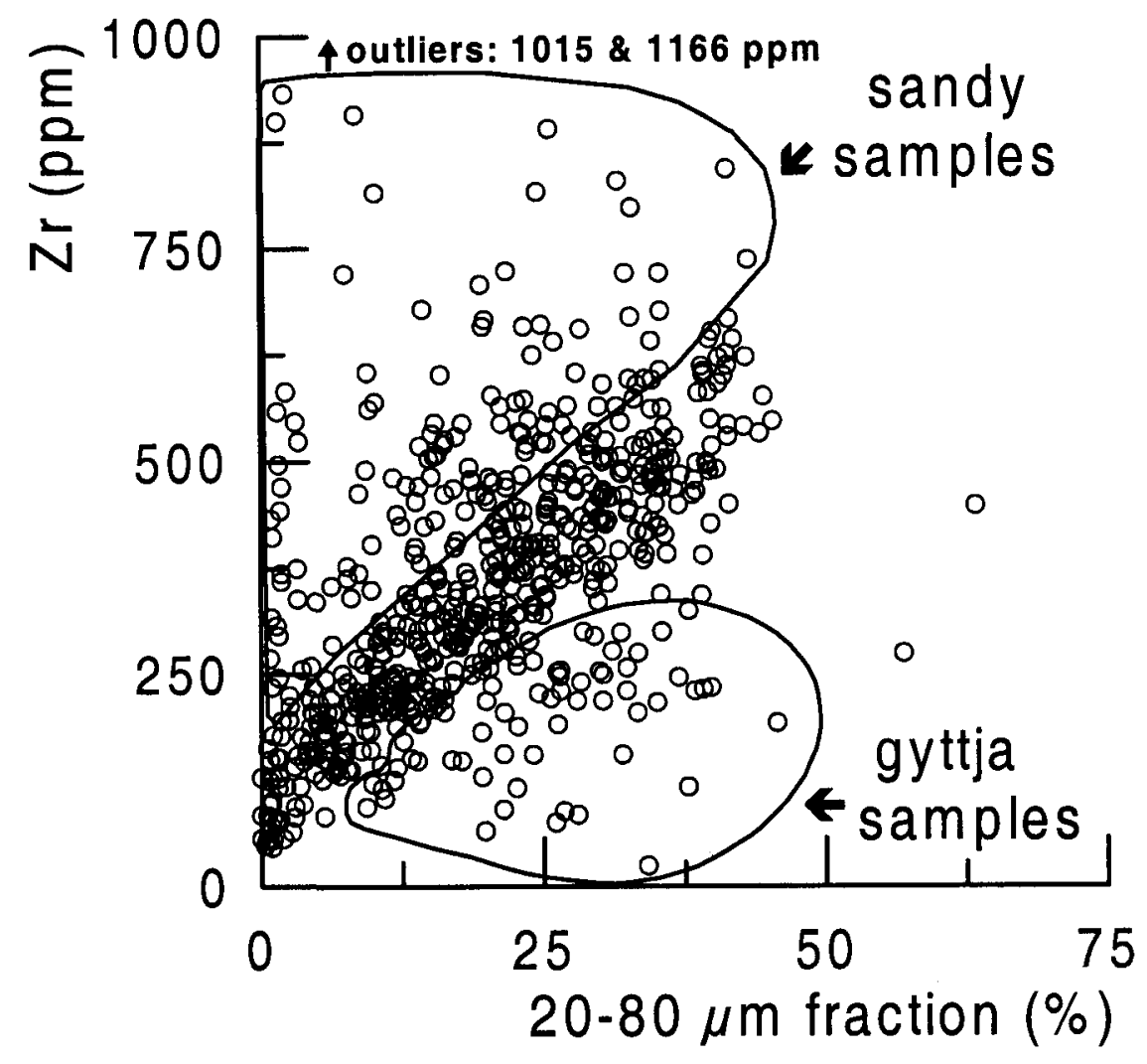

Fig. 7. The relationship between the contents of the $20-80 \mu \mathrm{m}$ fraction and $\mathrm{Zr}$ for bulk sediment samples. Note low values for $\mathrm{Zr}$ in gyttja samples and high values in sandy samples with $<30 \%$ of the $0-20 \mu \mathrm{m}$ fraction.

ate content, but increases with increasing $\mathrm{Al}_{2} \mathrm{O}_{3}$ or clay and fine-silt content as well. This suggests that $\mathrm{Sr}$ be built into phyllosilicates as well. Labelling further demonstrates elevated $\mathrm{MgO}$ contents (Fig. 4; ellipseshaped contour) and $\mathrm{Fe}_{2} \mathrm{O}_{3}$ contents (e.g., lower part of profiles $\mathrm{A}$ and $\mathrm{B}$ in Fig. 8) in several calcareous samples. The former is probably due to the substitution of Ca by $\mathrm{Mg}$ in carbonates (Van der Marel \& Van der Broek, 1962). The latter is due to the presence of calcareous gyttja/clay samples, which contain Fe bearing siderite and vivianite as well.

\section{Anomalies}

Six samples (five of which within one coring, but not successive) showed extreme values for $\mathrm{Pb}(375,486$, 188, 113, 76 and $75 \mathrm{ppm}$, respectively), five other samples for $\mathrm{Ni}(104,157,138,87$ and $87 \mathrm{ppm}$, respectively) and three for $\mathrm{Zn}(238,173,187 \mathrm{ppm})$. Recent anthropogenic pollution and laboratory contamination could be ruled out with absolute certainty after checking the position/chronology of these samples and their $\mathrm{Zn}, \mathrm{Cu}$ and $\mathrm{Cr}$ contents (showing normal values). The $\mathrm{Pb}$ and $\mathrm{Zn}$ accumulations were mainly found in humic clays and/or underneath peat layers. When these extreme values are excluded from the scatter plots, the $\mathrm{Pb}$ and $\mathrm{Zn}$ contents in some samples are still elevated ( 40 to $75 \mathrm{ppm}$ ). These samples appeared to be Subatlantic clays.

\section{Discussion}

\section{Natural compositional variability}

The bulk geochemistry of samples taken from unconsolidated sediments of the upper Kreftenheye and Betuwe Formations varies with granulometry. The mixing of a variety of minerals (mainly phyllosilicates, feldspars and quartz) hosted in different size fractions, causes natural variation in the abundance of both main and trace elements and their ratios. Quartz grains in the fine and coarse sand fractions account for the bulk $\mathrm{SiO}_{2}$ content. Phyllosilicates abound in the clay and fine-silt size fractions and host varying contents of $\mathrm{Al}_{2} \mathrm{O}_{3}, \mathrm{~K}_{2} \mathrm{O}, \mathrm{MgO}, \mathrm{TiO}_{2}$ and trace elements (Van den Broek \& Van der Marel, 1980; Moura \& Kroonenberg, 1990; Hakstege et al., 1993). K-feldspars, Na-feldspar and heavy minerals occur more frequently in the silt fraction (Van den Broek \& Van der Marel, 1980). Accordingly, a coarse sandy sample only containing $\mathrm{K}$-feldspar $\left(\mathrm{KAlSi}_{3} \mathrm{O}_{8}\right)$ exhibits a higher $\mathrm{K}_{2} \mathrm{O} / \mathrm{Al}_{2} \mathrm{O}_{3}$ ratio than a clayey silt sample, in which the same $\mathrm{K}$-feldspars are 'diluted' by Al-rich clay minerals (such as illite: $\mathrm{KAl}_{5} \mathrm{Si}_{7} \mathrm{O}_{20}(\mathrm{OH})_{4}$ ). Likewise, clayey overbank and stream sediments from the Meuse tributaries draining the Ardennes' Palaeozoic shales were found to be richer in $\mathrm{Al}_{2} \mathrm{O}_{3}, \mathrm{~K}_{2} \mathrm{O}$, several trace elements, etc. compared to overbank sediments of streams and rivers draining the coarser Tertiary 


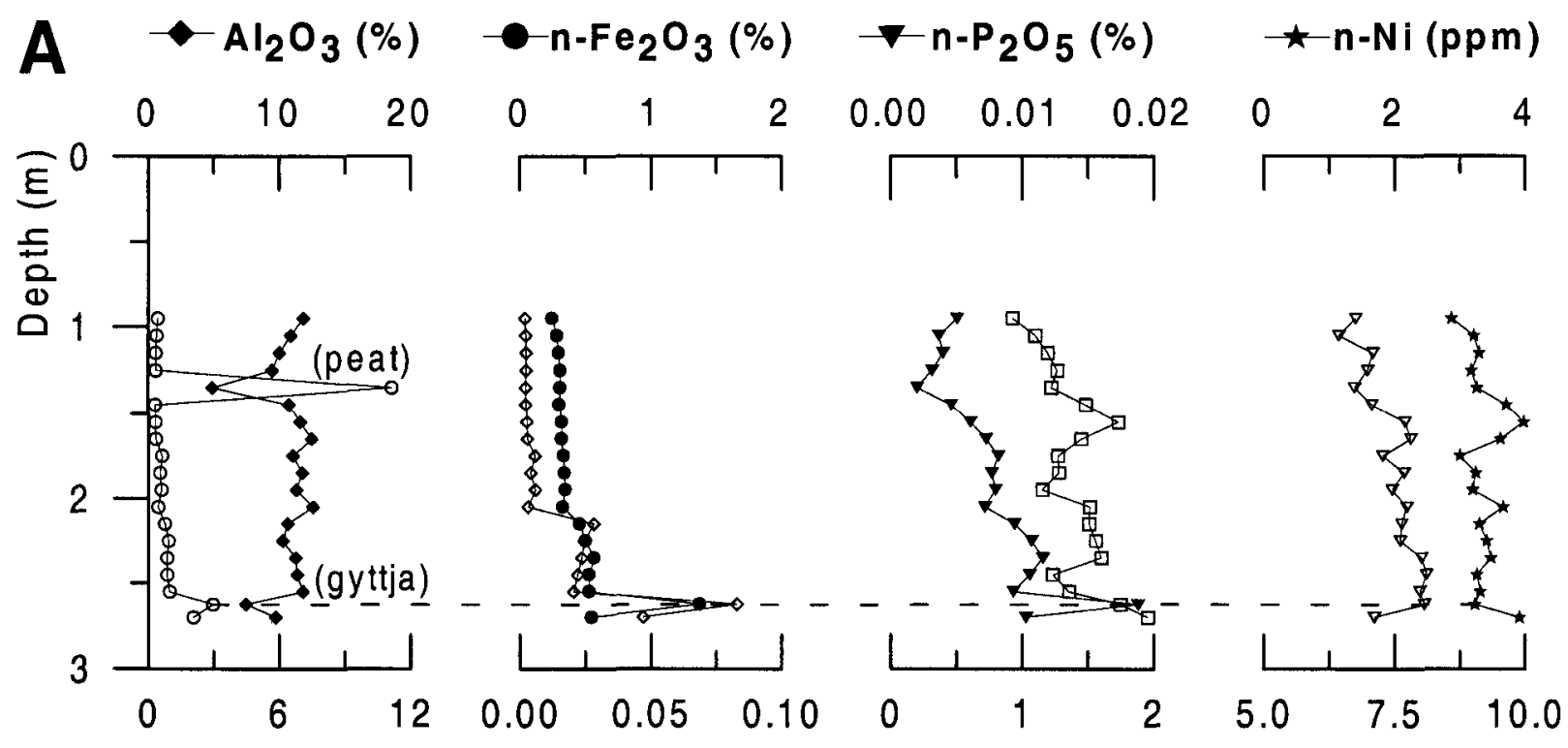

B

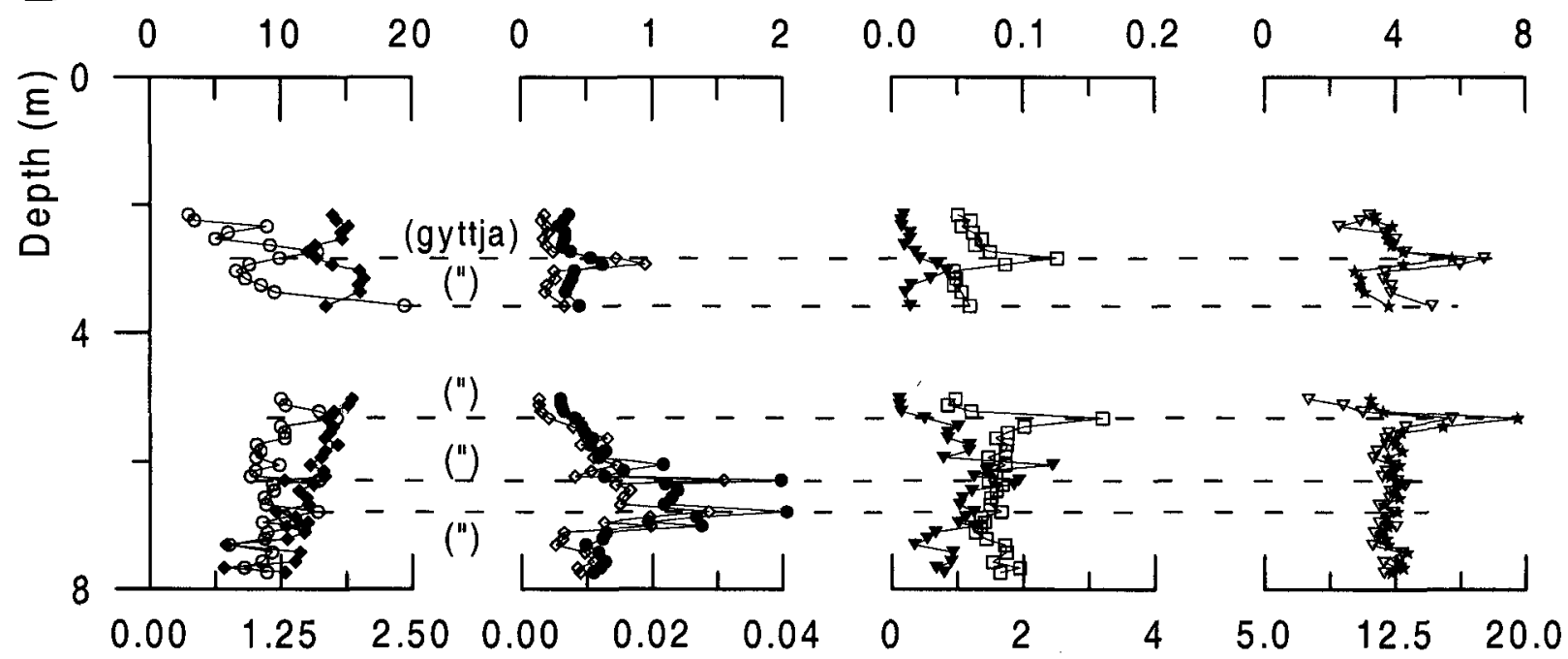

C

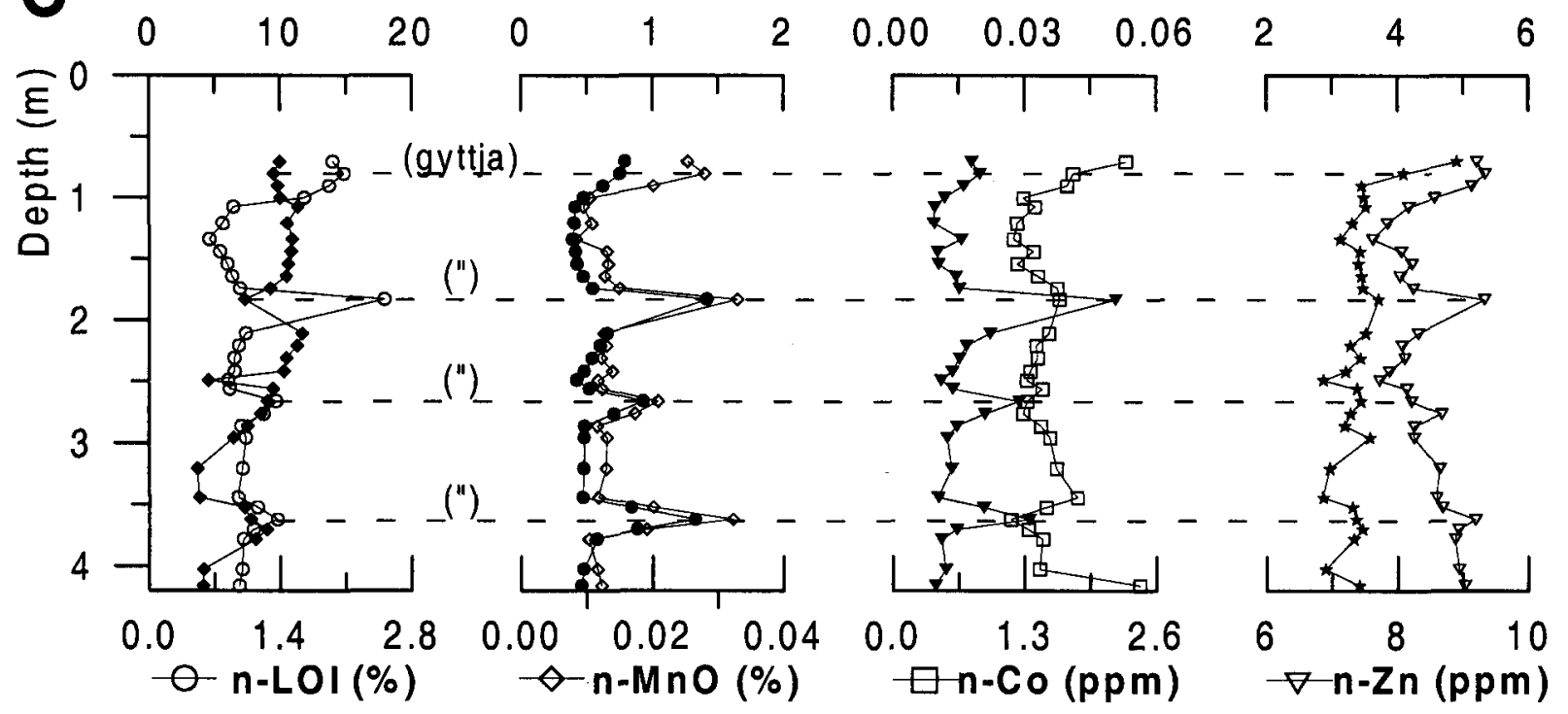

Fig. 8. Selection of $\mathrm{Al}_{2} \mathrm{O}_{3}$-normalised main and trace elements (n-...) for the vertical profiles from $\mathrm{A}$ (Beugen), B (Blitterswijck) and C (Keuter). Sample locations and lithology are shown in Figures 1 and 2. The uppermost peat intervals and the middle one in $B$ as well as the lowermost sands in $\mathrm{C}$ have not been sampled. Closed symbols correspond to upper $\mathrm{x}$-axes, while open symbols correspond to lower $\mathrm{x}$-axes. 


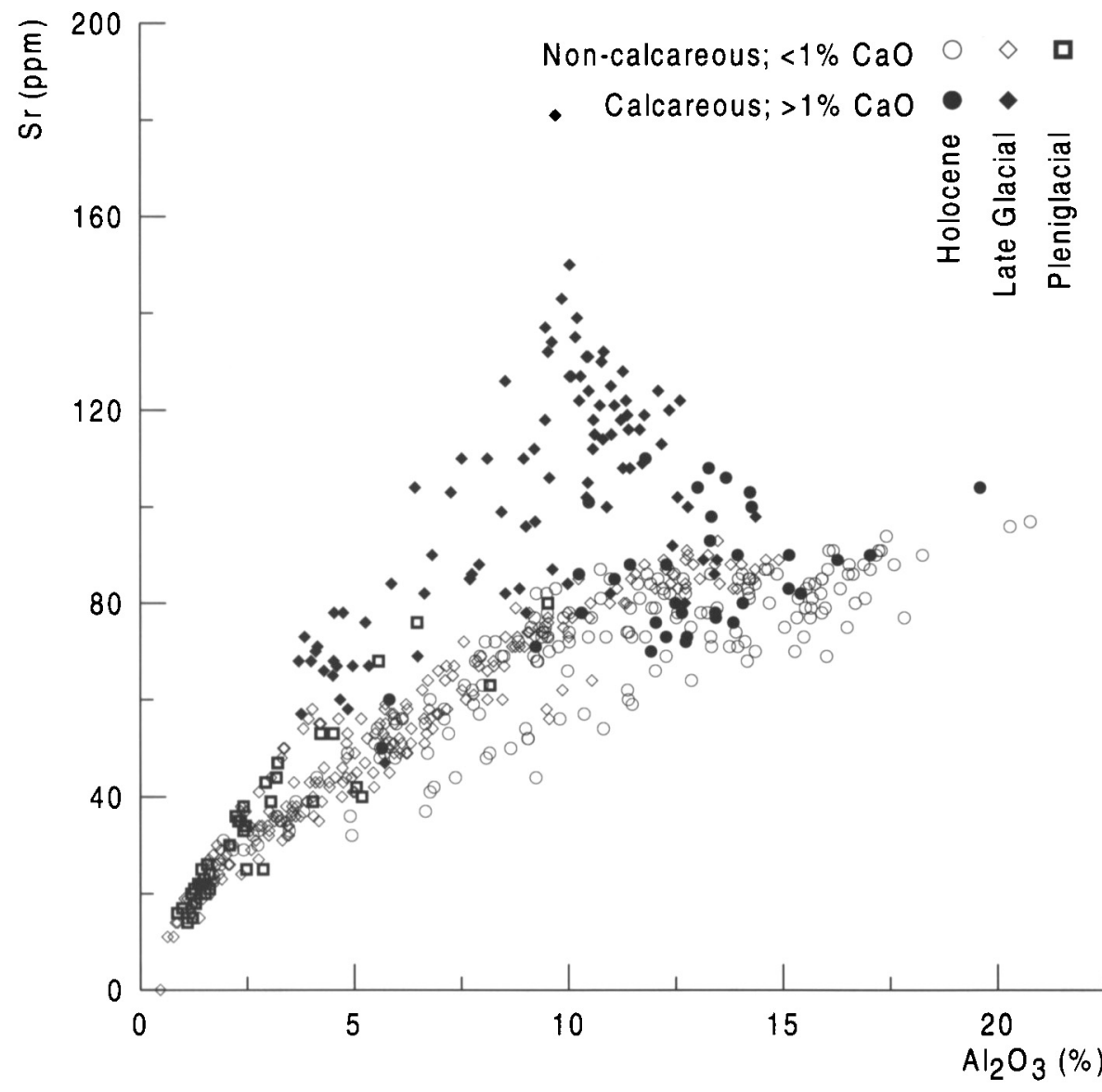

Fig. 9. The relationship between the contents of $\mathrm{Al}_{2} \mathrm{O}_{3}$ and $\mathrm{Sr}$. Closed symbols indicate calcareous samples $(>1 \%$ $\mathrm{CaO})$ and open symbols indicate noncalcareous samples $(<1 \% \mathrm{CaO})$. Note $\mathrm{Sr}$ enrichment in calcareous samples and the difference between Late Glacial and Holocene samples.

sands of northern Belgium (Van der Sluys et al., 1997). Any geochemical reference baseline for a particular region or geological unit should therefore certainly include grain-size measurements that preferably cover the whole range of sedimentological niches in that region or unit.

Apart from geochemical variation due to grain-size sorting processes, Late Glacial climate change introduced a systematic temporal compositional change into the bulk and clay geochemistry of Meuse sediments (Tebbens et al., 1998). Age labelling in scatter plots shows that the bulk composition of Meuse sediments cannot be considered constant on time scales of 1000-10,000 years. Chamley (1989) and Curtis (1990) already anticipated this by stating that climatic signals are likely to survive best in bulk compositional data of fine-grained Quaternary fluvial sediments. The contents of $\mathrm{K}_{2} \mathrm{O}, \mathrm{MgO}$ and $\mathrm{TiO}_{2}$ were found to be lower in Holocene samples than in Late Glacial and Pleniglacial samples with comparable $\mathrm{Al}_{2} \mathrm{O}_{3}$ contents. The ratios of $\mathrm{Ba}, \mathrm{Cr}, \mathrm{Rb}$ and $\mathrm{V}$ relative to $\mathrm{Al}_{2} \mathrm{O}_{3}$ are only slightly lower in Holocene sediments. When $\mathrm{Ba}, \mathrm{Cr}$ and especially $\mathrm{Rb}$ and $\mathrm{V}$ are plotted versus the $\mathrm{K}_{2} \mathrm{O}$ (Fig. 6) and $\mathrm{MgO}$ contents (not shown), however, a shift to considerably higher values relative to $\mathrm{K}_{2} \mathrm{O}$ and $\mathrm{MgO}$ in Holocene samples emerges. This suggests that the climatic scattering be due mainly to preferential depletion of $\mathrm{K}_{2} \mathrm{O}$ and $\mathrm{MgO}$.

Since the drainage area essentially remained unchanged during the glacial/interglacial transition, direct source-rock provenance changes cannot be held responsible. Instead, the Late Weichselian climatic amelioration induced higher landscape stability and stronger chemical weathering processes in the upstream drainage basins (Tebbens et al., 1998). Uptake and storage by the re-established vegetation cover and post-permafrost soil-profile percolation and successive leaching of basic cations to the groundwater may account for the withdrawal/loss of $\mathrm{K}$ and $\mathrm{Mg}$ from soil mineral environments on a landscape-wide scale (Bain et al., 1995; Berner et al., 1996; Korobova et al., 1997). Ultimately, this increased the supply of weathered soil-derived detrital clay minerals. Higher amounts of $\mathrm{K}$ - and $\mathrm{Mg}$-depleted smectite, vermiculite and their interstratifications to illite lowered the $\mathrm{K}_{2} \mathrm{O}$, $\mathrm{MgO}$ and $\mathrm{TiO}_{2}$ contents and raised the $\mathrm{Al}_{2} \mathrm{O}_{3}$ contents of Holocene bulk samples. Consequently, these samples have lower $\mathrm{K} / \mathrm{Al}, \mathrm{Mg} / \mathrm{Al}$ and $\mathrm{Ti} / \mathrm{Al}$ ratios and higher ratios of $\mathrm{Rb}, \mathrm{V}, \mathrm{Cr}$ and $\mathrm{Ba}$ to $\mathrm{K}_{2} \mathrm{O}$ and $\mathrm{MgO}$ compared to Late Glacial samples (Tebbens et al., 1998).

Post-depositional siderite and vivianite, formed 
during early diagenesis, raise the contents of $\mathrm{Fe}_{2} \mathrm{O}_{3}$, $\mathrm{MnO}$ and $\mathrm{P}_{2} \mathrm{O}_{5}$ in (clayey) gyttja samples (cf. Postma, 1982; Curtis, 1995; Huisman, 1997; Walraven et al., in press). Due to this post-depositional overprint and the $10-\mathrm{cm}$ interval sampling, any climatic influence on the $\mathrm{Fe}_{2} \mathrm{O}_{3}$ content relative to $\mathrm{Al}_{2} \mathrm{O}_{3}$ could not be substantiated. Walraven et al. (in press), however, infer two climate-induced diagenetic stages of siderite formation from detailed $\mathrm{cm}$-sampling of two Late Glacial gyttja deposits. They assume that the Fe- and Mn-(oxy)hydroxides have been deposited during the cold phases, whereas siderite preferentially precipitated during the warm phases. Poulton \& Raiswell (1996) performed sequential extractions on suspended loads, to demonstrate that glacial river systems are low in highly reactive $\mathrm{Fe}$ and that poorly reactive $\mathrm{Fe}$ dominates their total $\mathrm{Fe}$ contents. They found the reverse for present interglacial European rivers, and consider the larger fraction of highly reactive $\mathrm{Fe}$ in the present river basins to arise from increased (chemical) weathering as opposed to dominant physical weathering processes in glacial river systems.

The contents of the trace elements $\mathrm{Co}, \mathrm{Ni}$ and $\mathrm{Zn}$ in clayey gyttjas are higher than their natural occurrence in phyllosilicate minerals predicts. Historic mining of ore deposits since the Industrial Revolution is known to have raised the contents of $\mathrm{Pb}, \mathrm{Zn}, \mathrm{Cu}$ and As in recent Meuse and Geul overbank sediments (Leenaers, 1989; Hindel et al., 1996; Swennen et al., 1994, 1997; Swennen \& Van der Sluys, 1998a,b). In the present study, the samples were of unambiguous pristine nature, excluding effects of historic ore mining or coal slags on trace-element geochemistry. Hakstege et al. (1993) mention $\mathrm{Pb}$ and $\mathrm{Zn}$ accumulation in former vegetation horizons of old floodplain deposits. Huisman (1997) found similar accumulations of the same elements in Early and Middle Pleistocene organic subsurface samples. He suspected that $\mathrm{Ni}$ is released from Fe-hydroxides during glacial/interglacial groundwater fluctuations. Hill \& Aplin (1996) sampled unpolluted rivers with diverse contents of dissolved organic matter to find that $20-40 \%$ of total $\mathrm{Zn}$ and $60-80 \%$ of $\mathrm{Ni}$ and $\mathrm{Pb}$ were associated with fine colloidal organic material via humic and fulvic acid complexation. Our samples with $\mathrm{Ni}$ accumulation were situated in or below gyttja intervals. Apparently, the organic matter complexes force these trace metals to elevate the $\mathrm{Co}, \mathrm{Ni}, \mathrm{Pb}$ and $\mathrm{Zn}$ contents by subsequent flocculation with clay in the high-organicmatter gyttja or peat environment. Biological accumulation owing to vegetation growth may also have caused the Holocene organic-matter-rich profile to contain more trace elements in absolute sense (Korobova et al., 1997). Finally, Shotyk et al. (1998) mentioned enhanced atmospheric $\mathrm{Pb}$ influxes in a Swiss peat bog, which they attributed to increased soil erosion following two climate change events at around 10,590 (Younger Dryas) and $8230{ }^{14} \mathrm{C}$ years BP.

The elevated $\mathrm{Pb}$ contents in Subatlantic clays (younger than $2900{ }^{14} \mathrm{C}$ years $\mathrm{BP}$ ) probably reflect anthropogenic deforestation practices leading to the erosion of the upper organic soil horizons rich in bioaccumulated $\mathrm{Pb}$ or $\mathrm{Zn}$ (cf. Macklin et al., 1994; Korobova et al., 1997). Indeed, Shotyk et al. (1998) provide evidence for increased atmospheric lead deposition after $5320{ }^{14} \mathrm{C}$ years $\mathrm{BP}$, related to soil erosion caused by forest clearing and agricultural tillage. They reconstructed the beginning of increased lead pollution due to mining and smelting at about $3000{ }^{14} \mathrm{C}$ years BP. Likewise, Greenland ice-core analyses indicate an increase of atmospheric lead concentrations to four times the natural background values during about 2500-1700 years BP, the time of mining and smelting activities by the Greek and Roman civilisations (Hong et al., 1994). Human atmospheric pollution might therefore have elevated the $\mathrm{Pb}$ contents in the atmosphere and consequently in soils and sediments as early as 3000 years ago. This implies, as far as $\mathrm{Pb}$ is concerned, that the Subatlantic clayey sediments can - strictly seen - not be considered unpolluted.

\section{Prediction of natural contents}

The contents and ratios of main and trace elements in pristine samples of Late Glacial and Early Holocene Meuse sediments depend for the greater part $(70 \%$ of explained variation) on their granulometry. Climatic change and early diagenesis provide some variations on this theme. Pre-erosional weathering in interstadial or interglacial soil environments depletes clay minerals of $\mathrm{K}_{2} \mathrm{O}$ and $\mathrm{MgO}$ and causes relative $\mathrm{Al}_{2} \mathrm{O}_{3}$ enrichment. Siderite/vivianite accumulation and organic complexation in strongly organic gyttjas and peat elevate the contents of $\mathrm{Fe}_{2} \mathrm{O}_{3}, \mathrm{P}_{2} \mathrm{O}_{5}, \mathrm{MnO}, \mathrm{Co}, \mathrm{Ni}, \mathrm{Pb}$ and $\mathrm{Zn} . \mathrm{MgO}$ and $\mathrm{Sr}$ are elevated in calcareous samples. Heavy-mineral concentration in fine sands elevates their $\mathrm{Zr}, \mathrm{Nb}, \mathrm{Nd}$ and $\mathrm{Y}$ contents.

The causes of the most important factors in natural variation being clear, it is possible to predict the contents of major and trace elements as a function of sample granulometry, and to allow for siderite accumulation and lime content. The $\mathrm{Al}_{2} \mathrm{O}_{3}$ content showed the strongest factor loading to the clay and fine-silt factor (Table 1). The $\mathrm{Al}_{2} \mathrm{O}_{3}$ content is to be preferred as a proxy for the clay and fine-silt content instead of laser granulometry, because $\mathrm{Al}_{2} \mathrm{O}_{3}$ and oth- 
er elements can be measured simultaneously in the same sample (cf. Huisman \& Kiden, 1998). Moreover, the XRF measurements do not suffer from incomplete oxidised organic matter particles in strongly organic samples (unlike the grain-size measurements). Likewise, the $\mathrm{Fe}_{2} \mathrm{O}_{3}$ and $\mathrm{CaO}$ content show strongly positive factor loadings to the gyttja/ siderite and carbonate factors, respectively, and can be used to represent the siderite/vivianite or lime contents. In the case of $\mathrm{K}_{2} \mathrm{O}, \mathrm{MgO}$ and $\mathrm{TiO}_{2}$, it makes sense to distinguish between Holocene and Late Glacial/ Pleniglacial samples, to allow for the relative enrichment with $\mathrm{Al}_{2} \mathrm{O}_{3}$ in Holocene samples.

Table 2 gives data on the multiple linear regression models, with the $\mathrm{Al}_{2} \mathrm{O}_{3}, \mathrm{Fe}_{2} \mathrm{O}_{3}$ and $\mathrm{CaO}$ contents as independent variables. Most models are very good fits and have multiple correlation coefficients of $>0.85$ (or explain $>75 \%$ of variation). The Holocene fits show lower $\mathbf{R}^{2}$ values compared to the Late Glacial ones, stressing their greater variability. The lower ratios of $\mathrm{K}_{2} \mathrm{O}, \mathrm{MgO}$ and $\mathrm{TiO}_{2}$ to $\mathrm{Al}_{2} \mathrm{O}_{3}$ for Holocene samples are reflected in lower multiple regression coefficients (a values in Table 2). Finally, Table 3 gives some basic statistical data on the entire dataset to provide the interested reader with an idea of the averages, standard deviations, medians, minimal and maximal values.

\section{Conclusions}

Late Glacial and Early Holocene Meuse sediments deposited since 13,000 years $\mathrm{BP}$ and before $3000{ }^{14} \mathrm{C}$ years $\mathrm{BP}$ are unaffected by anthropogenic pollution and are of unambiguous pre-industrial or pristine nature. Therefore, well dated fine-grained Meuse residual channel infillings from this time interval offer wide possibilities for environmental research to determine the natural sedimentary compositional variation of major and trace elements.

Unconsolidated, reduced sediments show considerable compositional variation due to sorting processes, affecting the abundance of phyllosilicates in the clay and fine-silt size fractions and feldspar and quartz minerals mainly in the coarser-silt and sand fractions. The clay and fine-silt fraction is predominantly characterised by the elevated and covariant contents of $\mathrm{Al}_{2} \mathrm{O}_{3}, \mathrm{~K}_{2} \mathrm{O}, \mathrm{MgO}, \mathrm{TiO}_{2}$ and trace elements like $\mathrm{Ba}$, $\mathrm{Ce}, \mathrm{Cr}, \mathrm{Ga}, \mathrm{La}, \mathrm{Ni}, \mathrm{Pb}, \mathrm{Rb}, \mathrm{V}$ and $\mathrm{Zn}$. Weathering in soil environments under interstadial and interglacial climatic conditions causes a shift towards increasing $\mathrm{Al}_{2} \mathrm{O}_{3}$ contents and decreasing $\mathrm{K}_{2} \mathrm{O}, \mathrm{MgO}$ and $\mathrm{TiO}_{2}$ contents in Holocene samples. Consequently, the ratios of a variety of trace elements like $\mathrm{Ba}, \mathrm{Cr}, \mathrm{Rb}$ and $\mathrm{V}$ (that are typically related to clay minerals) to these main elements change. Thus, the composition of the 0 $20 \mu \mathrm{m}$ fraction cannot be considered constant over a period of 1000-10,000 years. This should be borne in mind when samples are chosen covering one large temporal interval or when samples of terrace overbank sediments of different age are compared, even when these overbanks show no signs of recent soil formation.

Post-depositional formation of siderite and vivianite in gyttjas strongly influences the $\mathrm{Fe}_{2} \mathrm{O}_{3} \mathrm{MnO}$ and $\mathrm{P}_{2} \mathrm{O}_{5}$ contents. $\mathrm{Co}, \mathrm{Ni}$ and $\mathrm{Zn}$ occur as natural accumulations in these samples, which are therefore not necessarily polluted. Natural processes of organic matter complexation suggest that the same applies to $\mathrm{Pb}$ in strongly organic samples. A small group of Subatlantic clays with elevated $\mathrm{Pb}$ contents, however, probably reflect increased atmospheric $\mathrm{Pb}$ input resulting from deforestation and Roman mining activities. In addition, the heavy-mineral content and the lime content are able to influence the background values of $\mathrm{Zr}, \mathrm{Nb}, \mathrm{Nd}, \mathrm{Y}$ and $\mathrm{MgO}$ and of $\mathrm{Sr}$, respectively. The composition of fine-grained Meuse sediments thus systematically varies both in time $(1000-10,000$ ka) and on a local to regional geological scale. Any environmental legislation should certainly account for this variation to be realistic.

\section{Note}

The present paper contributes to the International Geological Correlation Program (IGCP) 449.

\section{References}

Asselman, N. \& Middelkoop, H., 1996. Smerig slib. Sedimentatie op de uiterwaarden. Geografie 5: 8-12.

Bain, D.C., Duthie, D.M.L. \& Thomson, C.M., 1995. Rates and processes of mineral weathering in soils developed on greywackes and shales in the southern uplands of Scotland. Water, Air and Soil Pollution 85: 1069-1074.

Berendsen, H.J.A., Hoek, W.Z. \& Schorn, E.A., 1995. Late Weichselian and Holocene river channel changes of the rivers Rhine and Meuse in the Netherlands (Land van Maas en Waal). In: Frenzel, B., Vandenberghe, J., Kasse, C., Bohncke, S. \& Gläser, B. (eds): Paläoklimaforschung/ Palaeoclimate Research 14: 151-171.

Bleichrodt, G. \& Ensinck, E.F.J.M., 1994. De Maas slaat toe. Verslag hoogwater Maas December 1993. Internal Report Ministerie van Verkeer en Waterstaat, Directie Limburg (Maastricht): $32 \mathrm{pp}$.

Berner, R.A., Cochran, M.F., Moulton, K. \& Rao, J.-L. 1996. The quantitative role of plants in silicate weathering (ext. abstr.). In: Bottrell, S.H. (ed.): Proceedings of the Fourth International Symposium on the Geochemistry of the Earth's Surface. University of Leeds (Leeds): 513-516.

Bustamante, S.C.L., 1976. L'évolution Plio-Pléistocène du basin Mosa d'après ses minéraux lourds. Revue de Géographie Physique et de Géologie Dynamique 18: 291-300.

Buurman, P., Pape, Th. \& Muggler, C.C., 1997. Laser grain-size determination in soil genetic studies. 1. Practical problems. Soil Science 162: 211-218. 
Chamley, H., 1989. Clay sedimentology. Springer Verlag (Berlin): $620 \mathrm{pp}$.

Curtis, C.D., 1990. Aspects of climatic influence on the clay mineralogy and geochemistry of soils, palaeosols and clastic sedimentary rocks. Journal of the Geological Society 147: 351-357.

Curtis, C.D., 1995. Post-depositional evolution of mudstones 1: early days and parental influences. Journal of the Geological Society 152: 577-586.

Darnley, A.G., 1997. A global geochemical reference network: the foundation for geochemical baselines. Journal of Geochemical Exploration 60: 1-5.

Darnley, A.G., Björklund, A., Bølviken, B., Gustavsson, N., Koval, P.V., Plant, J.A., Steenfelt, A., Tauchid, M., Xuejing, X., Garrett, R.G. \& Hall, G.E.M. 1995. A global geochemical database for environmental and resource management. Recommendations for International Geochemical Mapping. Final report of IGCP Project 259. UNESCO (Paris): 122 pp.

Doppert, J.W.Chr., Ruegg, G.H.J., Van Staalduinen, C.J., Zagwijn, W.H. \& Zandstra, J.G., 1975. Formaties van het Kwartair en Boven Tertiair in Nederland. In: Zagwijn, W.H. \& Van Staalduinen, C.J. (eds.): Toelichting bij geologische overzichtskaarten van Nederland. Rijks Geologische Dienst (Haarlem): 11-76.

Goudriaan, J., 1995. De Maas slaat weer toe. Verslag hoogwater Maas januari/februari 1995. Internal Report Ministerie van Verkeer en Waterstaat, Directie Limburg (Maastricht): $31 \mathrm{pp}$.

Hakstege, A.L., Kroonenberg, S.B. \& Van Wijck, H. 1993. Geochemistry of Holocene clays of the Rhine and Meuse rivers in the central-eastern Netherlands. Geologie en Mijnbouw 71: 301-315.

Hill, D.M. \& Aplin, A.C. 1996. Role of colloids as carriers of metals in river waters (ext. abstr.). In: Bottrell, S.H. (ed.): Proceedings of the Fourth International Symposium on the Geochemistry of the Earth's Surface. University of Leeds (Leeds): 534536.

Hindel, R., Schalich, J., De Vos, W., Ebbing, J., Swennen, R. \& Van Keer, I., 1996. Vertical distribution of elements in overbank sediment profiles from Belgium, Germany and The Netherlands. Journal of Geochemical Exploration 56: 105-122.

Hong, S., Candelone, J.-P., Patterson, C.C. \& Boutron, C.F., 1994. Greenland ice evidence of hemispheric lead pollution two millennia ago by Greek and Roman civilizations. Science 265: 18411843.

Huisink, M., 1997. Late Glacial sedimentological and morphological changes in a lowland river in response to climatic change; the Maas, southern Netherlands. Journal of Quaternary Science 12: 209-223.

Huisman, D.J., 1997. Geochemical characterization of subsurface sediments in the Netherlands. Ph.D. thesis Wageningen Agricultural University: $175 \mathrm{pp}$.

Huisman, D.J. \& Kiden, P., 1998. A geochemical record of Late Cenozoic sedimentation history in the southern Netherlands. Geologie en Mijnbouw 76: 277-292.

Kasse, C., Vandenberghe, J. \& Bohncke, S.J.P. 1995. Climatic change and fluvial dynamics of the Maas during the Late Weichselian and Early Holocene. In: Frenzel, B., Vandenberghe, J., Kasse, C., Bohncke, S. \& Gläser, B. (eds.): Paläoklimaforschung / Palaeoclimate Research 14: 123-150.

Korobova, E.M., Veldkamp, A., Ketner, P. \& Kroonenberg, S.B., 1997. Element partitioning in sediment, soil and vegetation in an alluvial terrace chronosequence, Limagne rift valley, France: a landscape geochemical study. Catena 31: 91-117.

Kroonenberg, S.B., 1990. Geochemistry of Quaternary fluvial sands from different tectonic regimes. Chemical Geology 84: 8890.

Kroonenberg, S.B., 1994. Effect of provenance, sorting and weath- ering on the geochemistry of fluvial sands from different tectonic and climatic environments. In: Kumon, F. \& Yu, K.M. (eds.): Proceedings of the $29^{\text {th }}$ International Geological Congress 1992 (Kyoto), A: 69-81.

Leenaers, H., 1989. The dispersal of metal mining waste in the catchment of the River Geul, Belgium - The Netherlands. Netherlands Geographical Studies 102: 1-230.

Macklin, M.G., Ridgway, J., Passmore, D.G. \& Rumsby, B.T., 1994. The use of overbank sediment for geochemical mapping and contamination assessment: results from selected English and Welsh floodplains. Applied Geochemistry 9: 689-700.

Makaske, B. \& Nap, R.L., 1995. A transition from a braided to a meandering channel facies, showing inclined heterolithic stratification (Late Weichselian, central Netherlands). Geologie en Mijnbouw 74: 13-20.

Moura, M.L. \& Kroonenberg, S.B., 1990. Geochemistry of Quaternary fluvial and aeolian sediments in the southeastern Netherlands. Geologie en Mijnbouw 69: 359-373.

Ottesen, R.T., Bogen, J., Bølviken, B. \& Volden, T., 1989. Overbank sediment: a representative sample medium for geochemical mapping. Journal of Geochemical Exploration 32: 257-277.

Plant, J.A., Klaver, G., Locutura, J., Salminen, R., Vrana, K. \& Fordyce, F.M., 1997. The Forum of Geological Surveys Geochemistry Task Group inventory 1994-1996. Journal of Geochemical Exploration 59: 123-146.

Postma, D., 1982. Pyrite and siderite formation in brackish and freshwater swamp sediments. American Journal of Science 282: 1151-1183.

Poulton, S.W. \& Raiswell, R., 1996. Suspended river particulates as a potential source of iron for pyrite formation (ext. abstr). In: Bottrell, S.H. (ed.): Proceedings of the Fourth International Symposium on the Geochemistry of the Earth's Surface. University of Leeds (Leeds): 628-632.

Rang, M.C. \& Schouten, C.J., 1989. Evidence for historical heavy metal pollution in floodplain soils: the Meuse. In: Petts, G.E. (ed.): Historical change of large alluvial rivers: Western Europe. Wiley (Chichester): 127-142.

Salminen, R. \& Tarvainen, T., 1997. The problem of defining geochemical baselines. A case study of selected elements and geological materials in Finland. Journal of Geochemical Exploration 60: 91-98.

Shotyk, W., Weiss, D., Appleby, P.G., Cheburkin, A.K., Frei, R., Gloor, M., Kramers, J.D., Reese, S. \& Van der Knaap, W.O., 1998. History of atmospheric lead deposition since $12,370{ }^{14} \mathrm{C}$ yr BP from a peat bog, Jura Mountains, Switzerland. Science 281: $1635-1640$.

Swennen, R. \& Van der Sluys, J., 1998a. Environmental relevance of sedimentological and geochemical variations of heavy metals in vertical overbank sediment profiles. Special Volume International Association of Sedimentologists 'Environmental Sedimentology': $20 \mathrm{pp}$.

Swennen, R. \& van der Sluys, J., 1998b. Zn, Pb, Cu and As distribution patterns in overbank and medium order stream sediment samples: their use in exploration and environmental geochemistry. Journal of Geochemical Exploration 65: 27-45.

Swennen, R., Van Keer, I. \& De Vos, W., 1994. Heavy metal contamination in overbank sediments of the Geul River (East Belgium): its relation to former $\mathrm{Pb}-\mathrm{Zn}$ mining activities. Environmental Geology 24: 12-21.

Swennen, R., Van der Sluys, J., Hindel, R. \& Brusselmans, A., 1997. Geochemical characterisation of overbank sediments: a way to assess background reference data and environmental pollution in highly industrialised areas (such as Belgium and Luxembourg). Zeitblatt für Geologie und Paläontologie 1: 925-942.

Tebbens, L.A., Veldkamp, A. \& Kroonenberg, S.B., 1998. The im- 
pact of climate change on the bulk and clay geochemistry of fluvial residual channel infillings: the Late Weichselian and Early Holocene River Meuse sediments, The Netherlands. Journal of Quaternary Science 13: 345-356.

Tebbens, L.A., Veldkamp, A. \& Kroonenberg, S.B., 1999. Fluvial incision and channel downcutting as a response to Late Glacial and Early Holocene climate change: the lower reach of the Meuse river (the Netherlands). Journal of Quaternary Science 14: 59-75

Törnqvist, T.E., Weerts, H.J.T. \& Berendsen, H.J.A., 1993. Definition of two new members in the upper Kreftenheye and Twente Formations (Quaternary, The Netherlands): a final solution to persistent confusion? Geologie en Mijnbouw 72: 251-264.

Van den Berg, M.W., 1996. Fluvial sequences of the Maas, a $10 \mathrm{Ma}$ record of neotectonics and climate change at various time scales, PhD Thesis, Wageningen Agricultural University: $181 \mathrm{pp}$.

Van den Broek, J.M.M. \& Van der Marel, H.W., 1964. The alluvial soils of the Rivers Meuse, Roer en de Geul in the province of Limburg. Mededelingen van de Stichting voor Bodemkartering, Bodemkundige Studies 7: 1-75.

Van den Broek, J.M.M. \& Van der Marel, H.W., 1980. Properties and origin of sediments of the Meuse river in the Netherlands and Belgium. Pedologie 30: 243-273.

Van der Marel, H.W. \& Van den Broek, J.M.M., 1962. Calciummagnesium and potassium-magnesium relations in loess soils of Limburg. Boor en Spade 12: 103-110.

Van der Sluys, J., Brusselmans, A., De Vos, W. \& Swennen, R., 1997. Regional geochemical mapping of overbank and stream sediments in Belgium and Luxembourg. III. Geochemical maps of Belgium and Luxembourg based on overbank and active stream sediments. Belgian Geological Survey Professional Paper 283: 1- 93.

Walraven, N., Beets, C.J., Kasse, C., Bohncke, S.J.P., Van Os, B.J.H. \& Huisman, D.J. (in press). Climate induced formation of authigenic minerals in a meander fill of the river Maas. Palaeogeography, Palaeoclimatology, Palaeoecology.

Westerhoff, W., Broertjes, J.P. \& Van den Berg, M.W., 1990. Excursiegids 30e Belgisch-Nederlandse Palynologen Dagen (Arcen 45 oktober 1990). Vrije Universiteit (Amsterdam): 54 pp.

Wolterbeek, H.Th., Verburg, T.G. \& Van Meerten, Th.G., 1996. On the 1995 flooding of the rivers Meuse, Rhine and Waal in the Netherlands: metal concentrations in deposited river sediments. Geoderma 71: 143-156. 